University of South Carolina

Scholar Commons

Faculty Publications

Law School

$10-2009$

From Privacy to Liberty: The Fourth Amendment after Lawrence

Thomas P. Crocker

University of South Carolina School of Law, crocketp@law.sc.edu

Follow this and additional works at: https://scholarcommons.sc.edu/law_facpub

Part of the Constitutional Law Commons

Recommended Citation

Thomas P. Crocker, From Privacy to Property: The Fourth Amendment After Lawrence, 57 UCLA L. Rev. 1 (2009-2010)

This Article is brought to you by the Law School at Scholar Commons. It has been accepted for inclusion in Faculty Publications by an authorized administrator of Scholar Commons. For more information, please contact digres@mailbox.sc.edu. 


\section{From PRIVACY TO LIBERTY: THE FOURTH AMENDMENT AFTER LAWRENCE}

\section{Thomas P. Crocker}

This Article explores a conflict between the protections afforded interpersonal relations in Lawrence $v$. Texas and the vulnerability experienced under the Fourth Amendment by individuals who share their lives with others. Under the Supreme Court's third-party doctrine, we have no constitutionally protected expectation of privacy in what we reveal to other persons. The effect of this doctrine is to leave many aspects of ordinary life shared in the company of others constitutionally unprotected. In an increasingly socially networked world, the Fourth Amendment may fail to protect precisely those liberties-to live in the company of others free from state surveillance and intrusion-the Constitution should protect. Against the background of the third-party doctrine, we guarantee our privacy only by avoiding ordinary acts of interpersonal sharing. By contrast, the Court in Lawrence explains that intimate conduct occurring within protected personal relationships constitutes a private sphere wherein government may not intrude. Because the third-party doctrine views privacy narrowly, this Article develops a framework for revising Fourth Amendment jurisprudence in light of Lawrence's protection for interpersonal liberty. By following the lessons of Lawrence, this Article proposes a way to reorient Fourth Amendment jurisprudence away from its focus on privacy in order to protect interpersonal liberty.

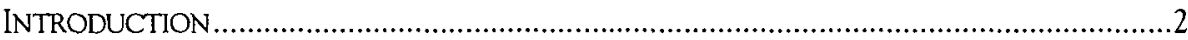

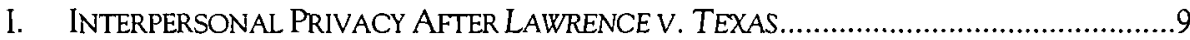

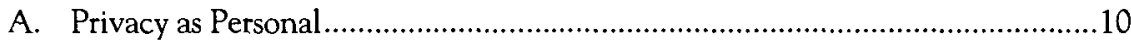

B. Liberty as Interpersonal...................................................................... 16

C. Autonomy, Intimacy, and Dignity: The Interpersonal Values of Liberty and Privacy

* Assistant Professor of Law, University of South Carolina School of Law. J.D. Yale Law School; Ph.D. Vanderbilt University. A version of this Article was selected for presentation at the 2009 Law \& Humanities Junior Scholar's Workshop held at the Georgetown Law Center. I benefited greatly from the comments and community, and would like to thank all who participated. In particular, I owe thanks to Teemu Ruskola and Anne Dailey for their insightful commentaries. I would also like to thank Josie Brown, Amy Cohen, Charlton Copeland, Holly Crocker, Ben Depoorter, Amy Dillard, David Fagundes, Jessie Hill, Zachary Kramer, Dan Markel, John Muckelbauer, Chad Oldfeather, Penny Pether, Adam Thurschwell, Steven Vladek, Howard Wasserman, Lesley Wexler, and Verity Winship for helpful comments and conversations along the way. I would also like to thank Kristina Cooper, Ashley Graham, and Chris Kenney for their excellent research assistance. 


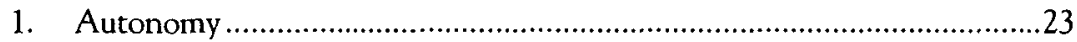

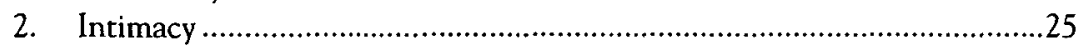

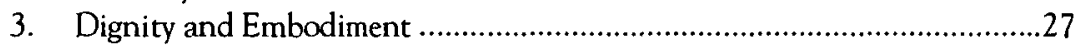

II. INTERPERSONAL PRIVACY UNDER THE FOURTH AMENDMENT ....................................32

A. Assuming the Risk of Disclosure ....................................................................34

B. Assuming the Risk of a Shared Life...............................................................40

III. THE FOURTH AMENDMENT AND THE PROBLEM OF SHARED PRIVACY.........................48

A. Contested Expectations and Social Control.....................................................49

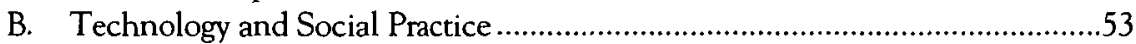

IV. LIBERTY UNDER THE FOURTH AMENDMENT: A SUBSTANTIVE INQUIRY ...................56

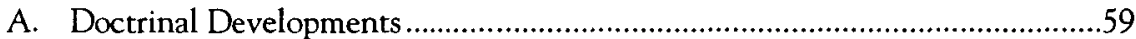

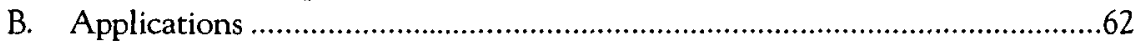

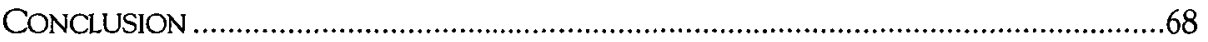

\section{INTRODUCTION}

Wanting to stay more closely connected with her close social network of friends, Jane signs up for a new cell-phone service.' Utilizing her phone's global positioning technology, she subscribes to a service that tracks her and her friends' whereabouts. With this service, she can find her friends easily and they can find her-down to the exact spot where she is currently reading a book over a cup of coffee. Joe does not have to wonder if Jane is currently at their favorite coffee shop. His phone will tell him. Neither Jane nor Joe intend to reveal to all the world their whereabouts. Their phones help them keep track of their friends and family-their chosen close social networks. Through the same service, each of their phones will also inform the police of their location, should the police become interested. No Fourth Amendment requirements of warrants or probable cause stand between the police and Jane's social network.

As far as the Fourth Amendment is concerned, government officials are entitled to access information that individuals publicly reveal. The Supreme Court has construed the Fourth Amendment to provide no protection for information voluntarily revealed to third parties: "[T]he Fourth Amendment does not prohibit the obtaining of information revealed to a third party and conveyed by him to Government authorities, even if the information is revealed on the assumption that it will be used only for a limited purpose." Effectively, what a person reveals to one, she reveals to all. Because Jane

1. See, e.g., Amol Sharma \& Jessica E. Vascellaro, Phones Will Soon Tell Where You Are, WALL ST. J., Mar. 28, 2008, at A1.

2. United States v. Miller, 425 U.S. 435, 443 (1976). 
reveals her location at all times to her group of friends, as well as her cellphone service provider, she has no constitutionally protected expectation of privacy. State agents may effectively become part of Jane's social network, monitoring her movements just as if they were one of her friends. ${ }^{3}$

The third-party doctrine yielding this outcome has been much maligned in the legal academy. ${ }^{4}$ Nonetheless, it persists, despite allowing officials to infringe upon the liberty of persons to live their lives shared in the company of others free from government intrusion. As Mary Coombs has argued, "current fourth amendment jurisprudence is impoverished and distorted by neglecting the ways in which privacy embodies chosen sharing." Surreptitious and suspicionless monitoring of our relations with others-what we reveal to third parties-this Article argues, undermines more than our right to privacy. Such activities undermine the conditions of ordinary personal life shared in the company of others, assumed to be secure in the blessings of liberty. Liberty, however, has not been the focal consideration of Fourth Amendment jurisprudence. Privacy has.

Both the Fourth Amendment and the Due Process Clauses of the Fifth and Fourteenth Amendments protect privacy, though they do so under different doctrinal frameworks. Both protect the liberty of persons to live free from government intrusion into private spheres of their lives. Despite these similarities of overall purpose, the Supreme Court's decision in Laurence v. Texas ${ }^{6}$ diverges from Fourth Amendment doctrine over how to view acts of

3. Moreover, when sitting in the coffee shop, she is located in a public place. Police are free to conduct surveillance of her public movements with no requirement of individualized suspicion. See United States v. Karo, 468 U.S. 705, 721 (1984) (holding that there is no expectation of privacy in public movements); United States v. Knotts, 460 U.S. 276, 281-82 (1983) (same).

4. See, e.g., Christopher Slobogin, Privacy at Risk: The New Government SURVEILlanCE AND THE FOURTH AMENDMENT (2007); Donald L. Doemberg, "Can You Hear Me Now?": Expectations of Privacy, False Friends, and the Perils of Speaking Under the Supreme Court's Fourth Amendment Jurisprudence, 39 IND. L. REV. 253, 284 (2006) ("The harm that the Amendment protects against is the loss of the sense of security that inevitably accompanies the idea that no matter where one is, and no matter what one does, the government may be listening or watching."); Daniel J. Solove, Fourth Amendment Codification and Professor Kerr's Misguided Call for Judicial Deference, 74 FORDHAM L. REV. 747, 753 (2005) ("The third-party doctrine presents one of the most serious threats to privacy in the digital age."); Scott E. Sundby, "Everyman"'s Fourth Amendment: Privacy or Mutual Trust Between Government and Citizen?, 94 COLUM. L. REV. 1751, 1761 (1994) (criticizing the Court's reliance on privacy because "[ilf an individual's privacy is already largely abrogated, any additional privacy intrusions will appear to be only incremental by comparison"). But see, Orin S. Kerr, The Case for the Third-Party Doctrine, 107 MICH. L. REV. 561 (2009) (defending the third-party doctrine).

5. Mary I. Coombs, Shared Privacy and the Fotrth Amendment, or the Rights of Relationships, 75 CAL. L. REV. 1593, 1593 (1987). Moreover, she argues that "[a] view of the world that recognizes the essential interconnectedness of people and the importance of intimacy and sharing is foreign to the atomistic social theory underlying the Court's present doctrine." Id. at 1635.

6. 539 U.S. $558(2003)$. 
interpersonal sharing. Persons who share their lives with others through intimate and expressive relationships receive protection from government interference under due process, but these same acts of sharing render persons vulnerable to government intrusion under the Fourth Amendment. The Laurence Court resolved the issue whether a State could criminalize certain kinds of private, intimate conduct "by determining whether the petitioners were free as adults to engage in the private conduct in the exercise of their liberty under the Due Process Clause of the Fourteenth Amendment to the Constitution." This Article argues that Lawrence's emphasis on liberty provides a fruitful way of reorienting Fourth Amendment protections when considering particular kinds of interpersonal relationships.

The doctrinal conflict unfolds as follows. In the due process context, the Supreme Court describes the value of privacy as protecting "a promise of the Constitution that there is a realm of personal liberty which the government may not enter." In the Fourth Amendment context, the Court explains that we have "[t]he right to privacy, no less important than any other right carefully and particularly reserved to the people." Both provisions seek to preserve a realm of personal life free from unwarranted state intrusion. Due process protects realms of personal liberty, while the Fourth Amendment protects a right to privacy. These two doctrines have developed in relative isolation from each other. Through the Fourteenth Amendment doctrine of privacy as protected by the liberty of the Due Process Clause, the Court has examined the substantive context and effects of government practice on the lives of persons. Through Fourth Amendment privacy as protected against unreasonable searches and seizures, the Court has established procedural protections such as the warrant requirement to constrain government officials. ${ }^{10}$ Police are required to follow Fourth Amendment procedures, however, only when they conduct a search or seizure as defined by the Court. To determine whether a Fourth Amendment search or seizure has occurred, the Court looks to whether it can find a suitable social expectation of privacy, where privacy is narrowly construed to mean secret, undisclosed, or publicly concealed. By contrast, under due process, the Court examines the effects on the lives of individuals impacted by government policy with more exacting scrutiny, often

7. Id. at 564 .

8. Id. at 578 (quoting Planned Parenthood of Se. Pa. v. Casey, 505 U.S. 833, 847 (1992)).

9. Mapp v. Ohio, 367 U.S. 643, 656 (1961).

10. See Katz v. United States, 389 U.S. 347, 357 (1967) ("[S]earches conducted outside the judicial process, without prior approval by judge or magistrate, are per se unreasonable under the Fourth Ameridment."); Jones v. United States, 357 U.S. 493, 497 (1958) ("It is settled doctrine that probable cause for belief that certain articles subject to seizure are in a dwelling cannot of itself justify a search without a warrant."). 
demanding a compelling government reason for any interference with individual liberties.

In Laurence, the Court begins by acknowledging that "[l]iberty protects the person from unwarranted government intrusions into a dwelling or other private places."' This statement could refer equally to the protection afforded the intimate bedroom against invasions of liberty under due process as it does the protection granted the home against unreasonable searches and seizures under the Fourth Amendment. Writing for the Court, Justice Kennedy continues: "Freedom extends beyond spatial bounds. Liberty presumes an autonomy of self that includes freedom of thought, belief, expression, and certain intimate conduct." ${ }^{\prime \prime 2}$ As the Laurence Court explains, intimate conduct is inseparable from the personal relationships in which the conduct has meaning and therefore constitutes a private sphere where government may not intrude.

In contrast, the Court affirms in cases like Georgia v. Randolph ${ }^{13}$ that intimate relationships render us vulnerable to the consent those with whom we share our lives might give the police. ${ }^{14}$ For Laurence, an intimate relationship is protected through the liberty we have to live our lives free from government domination, yet for Randolph, an intimate relationship may become an opportunity for government intrusion into the relationship or the home. Under the Fourth Amendment, we assume the risk that those with whom we share are, or will become, figurative agents of the State and thereby grant the State access to what we have shared. We preserve our privacy only by avoiding ordinary acts of interpersonal sharing. From the due process perspective, to limit privacy in this manner undermines "the liberty of persons to choose" ${ }^{\text {"15 }}$ to enter personal relationships free from government intrusion.

These two doctrinal frameworks — each purporting to protect the privacy and liberty of the individual-are in considerable tension. If personal relationships "safeguard[] the ability independently to define one's identity that is central to any concept of liberty,"16 and if the Constitution protects "personal bond[s] that [are] more enduring," ${ }^{, 17}$ then the Fourth Amendment framework that allows government officials to exploit personal relationships should be revised in light of Laurence.

11. Laurence, 539 U.S. at 562.

12. Id.

13. 547 U.S. 103 (2006).

14. Id. at 109-11. Although the Court ultimately denies police the authority to search in the particular circumstances of this case, see infra part II.B, it affirms the general proposition that we assume the legal risks of disclosure when sharing with others. Id.

15. Laurence, 539 U.S. at 567.

16. Roberts v. U.S. Jaycees, 468 U.S. 609,619 (1984).

17. Laurence, 539 U.S. at 567. 
So far this discussion has described the problem only in terms of constitutional doctrine. More than doctrine is at stake, however, since the Constitution constructs the conditions under which ordinary life is lived. Ordinary life involves sharing with other persons in ways that are simultaneously private and public. A typical day for an ordinary person will involve sharing thoughts, information, ideas, intimacies, conversations, company, friendships, associations, dwellings, and public spaces. These activities are private to the extent that they constitute our sphere of personal social relations as distinguished from a sphere of civic or official relations. These activities are public insofar as they involve social coordination and take place in public spaces-in offices, parks, restaurants, "public" buildings, churches, streets, sidewalks, etc. ${ }^{18}$ A single activity may entail both private and public aspects. A conversation with a friend on a park bench may be a private conversation insofar as it is not intended for public broadcast, but is also public if a parkgoer happens to look or an eavesdropper happens to listen. Privacy and publicity do not define entirely separate spheres of life. ${ }^{19}$ Jane's participation in her cell phone provider's social networking service illustrates the limited public, but still private, nature of ordinary life shared among friends. Her participation in the service reflects the value she places on staying connected with her close personal relations, but does not reflect a desire or expectation she has to make her movements known to the general public.

Fluid boundaries between what is private, though in the company of others, and what is genuinely public, even if unnoticed by others, shape how we live ordinary life. We define the boundaries of our relationships with others by both sharing with and withholding aspects of our lives. How much we share and the substance of what we share with others determines the closeness of a relationship. Ordinarily, the more one shares with another, the more that sharing implicates interpersonal structures of mutual trust, care, and affection. Undercutting the notion that privacy requires nondisclosure, the more we share, the more private and personal our relationships with others often become. By contrast, acts of nondisclosure define our most public and impersonal relations with others.

Law is not a neutral player in this dynamic. If public exposure forfeits privacy protections, then how constitutional doctrine defines public exposure determines what aspects of ordinary life receive protection from government

18. See WOLFGANG SOFSKY, PRIVACY: A MANIFESTO 7 (Steven Rendall, trans., Princeton U. Press 2007) ("People leave more traces behind them than they realize.").

19. See Lior Jacob Strahilevitz, A Social Networks Theory of Privacy, 72 U. CHI. L. REV. 919, 923-25 (2005). 
interference. What receives constitutional protection in turn shapes the boundaries of ordinary life.

It is perhaps too much to hope that the Supreme Court will reverse course and abandon the third-party doctrine in order to protect wider spheres of shared privacy. Constitutional law, however, does not depend on existing doctrine alone. ${ }^{20}$ It also depends on judicial selection and vision-the ability to see constitutional provisions in a new light. ${ }^{21}$ The third-party doctrine may be good law, here to stay, but privacy is not the lone object of Fourth Amendment protection. Laurence suggests another route of inquiry in shared privacy situations: Ask whether a search invades a protected sphere of liberty.

This Article develops an understanding of Laurence as protecting the interpersonal relationships constitutive of everyday life. ${ }^{22}$ Interpersonal relationships, Laurence instructs, are intrinsic to the liberty of individuals who share their lives with others in intimacy or collaborative association. When the State criminalizes conduct important to interpersonal relationships-whether it bans contraceptives, dictates the membership criteria for an expressive association, or stigmatizes homosexual sodomy-the State invades a protected sphere of liberty. Criminal prohibitions are not the only means of government domination. The State also invades the private sphere of interpersonal relations by exploiting the vulnerability that attends all acts of sharing. By gaining access to everything we share with others, whether it is information, conversations, networks, dwellings, belongings, or spaces, the State is able to assume the position of the one with whom we have shared. By assuming this position, the State risks becoming a dominant presence in the interpersonal relationships upon which the liberty of persons depends. If government were to assert a dominant presence in the private spheres of our lives, then liberty, as the basis for both freely chosen action and for political consent, would be undermined. Accordingly, this Article develops a framework for reorienting Fourth Amendment jurisprudence in light of Laurence's protection for interpersonal liberty. Focused primarily on due process liberty, not privacy, Laurence protects against forms of state intrusion into a person's home

20. Professor Jed Rubenfeld, for example, has recently called for reorienting Fourth Amendment inquiry to ask "whether the search-and-seizure power the state has asserted could be generalized without destroying the people's right of security." Jed Rubenfeld, The End of Privacy, 61 STAN. L. REV. 101, 131 (2008). Under Rubenfeld's approach, the Court should hew closely to Fourth Amendment text to protect the people's right to security rather than their right to privacy.

21. See Thomas P. Crocker, Envisioning the Constitution, 57 AM. U. L. REV. 1, 3 (2007).

22. Laurence's rational is not entirely transparent, making possible either broad or narrow readings. See Elizabeth M. Glazer, When Obscenity Discriminates, 102 Nw. U. L. REV. 1379, 1411-18 (2008) (discussing different ways of reading Laurence). This article chooses to read Laurence broadly. 
and intimate life in ways that are instructive for overcoming some of the worst consequences of the Fourth Amendment's third-party doctrine.

The Article unfolds as follows. Part I examines how choices about personal matters occur within relationships into which the State may not legitimately intrude-whether the choices are about marriage, child rearing, sexual relations, or even childbirth. Privacy, though usually treated as a condition of the individual alone, is often interpersonal. Although the Court claims in Laurence that "[1]iberty presumes an autonomy of self," which includes the freedom of "certain intimate conduct," autonomous persons are not protected in isolation from the relationships that give their lives meaning. We experience and expect privacy in the company of the others with whom we share our lives. Part I concludes that the right to privacy against government intrusion, even in public, is part of the liberty protected both by Laurence and by the right to associate in cases such as Roberts $v$. United States Jaycees $^{24}$ and Boy Scouts of America v. Dale. ${ }^{25}$

Having examined the interpersonal nature of privacy and liberty, the Article proceeds in Part II to explore how interpersonal relationships become sources of personal vulnerability under the Fourth Amendment. As constructed through Fourth Amendment doctrine, a shared life is a life fraught with assumed risks. Under the doctrinal framework developed in Katz $v$. United States, ${ }^{26}$ we receive Fourth Amendment protection against government searches only when we have a reasonable expectation of privacy. We do not have an expectation of privacy, the Court instructs, when we reveal what was undisclosed to others. As the Court explains, when we share aspects of our lives with others, we make ourselves vulnerable to them, by assuming the risk that they may inform state officials or consent to government searches in our absence. $^{27}$ Accordingly, the State has an often unconstrained opportunity to become a dominant presence in our lives, in conflict with the constitutional protections afforded to interpersonal relations.

Part III explores two ways that the assumption-of-risk doctrine undermines core constitutional values. When the State becomes a dominant presence in our interpersonal lives, the State undermines vital social practices through which we form our personal identities. Moreover, contested Supreme Court constructions of social expectations of privacy can in turn influence future

23. Lawrence v. Texas, 539 U.S. 558, 562 (2003).

24. 468 U.S. $609(1984)$.

25. 530 U.S. $640(2000)$.

26. 389 U.S. 347 (1967).

27. See Georgia v. Randolph, 547 U.S. 103, 109-11 (2006); Illinois v. Rodriguez, 497 U.S. 177 (1989); United States v. Jacobsen, 466 U.S. 109, 117 (1984). 
social practices. In particular, where new forms of technologically enabled social networking conflict with the Court's pronouncements on social expectations, reconsideration of current doctrine is in order. This section argues that we risk allowing government practices to undermine fundamental conditions of otherwise protected personal and political life. In light of these problems, Part IV suggests that we recognize that the Fourth Amendment protects not only privacy, but also liberty. Courts should adopt a substantive Fourth Amendment inquiry that examines the nature of the underlying relationship into which government agents wish to intrude. If the intrusion implicates a protected interpersonal relationship, then the State must follow default Fourth Amendment procedures in order to conduct a valid search. This Article concludes that Fourth Amendment jurisprudence should be reoriented and developed in light of Laurence to secure social practices and expectations of shared interpersonal liberty.

\section{INTERPERSONAL PRIVACY AFTER LAWRENCE V. TEXAS}

Constitutional privacy developed along two trajectories. First, by focusing on matters of procreation, family, and marriage, the Supreme Court recognized a right to privacy. Although the Constitution does not specifically refer to privacy, the Court grounded the right of privacy in both particular Bill of Rights provisions and in the structure of particular rights taken in combination. Second, by articulating the value protected by the Fourth Amendment prohibition against unreasonable searches and seizures, the Court recognized a core right to privacy in one's person, home, papers, and effects. Again, the Constitution does not explicitly name privacy for protection. Nonetheless, the Court developed a Fourth Amendment jurisprudence focused on protecting reasonable expectations of privacy.

As these different trajectories illustrate, "privacy" does not always refer to precisely the same thing. As Daniel Solove has argued, "[t]he word 'privacy' is currently used to describe a myriad of different things: freedom of thought, control over personal information, freedom from surveillance, protection of one's reputation, protection from invasions into one's home," and so on. ${ }^{28}$ Solove, following Ludwig Wittgenstein, suggests that the concept of "privacy" forms a "family resemblance" ${ }^{129}$ of related characteristics, but that it does not denote one, particular feature of the world. This conceptual

28. Daniel J. Solove, Conceptualizing Privacy, 90 CAL. L. REV. 1087, 1095 (2002).

29. Id. at 1095-99; see LUDWIG WITTGENSTEIN, PHILOSOPHICAL INVESTIGATIONS §§ 6667 (G.E.M. Anscombe trans., 1958). 
complexity is made even more difficult because constitutional protections of privacy, which lack an explicit textual reference, are closely related to protections of liberty, which do have a solid textual grounding. Often both privacy and liberty describe the same or similar kinds of protections from state interference. Sometimes liberty, as in the case of Laurence, has a broader scope than privacy, especially when privacy is more narrowly construed as personal and individual. Regarding the first trajectory focused on marriage and procreation, the Court has shifted significantly away from further development of privacy protections in favor of protecting a realm of personal and interpersonal liberty grounded in the Due Process Clauses of the Fifth and Fourteenth Amendments. Capable of protecting the same sphere of private and personal life as the right to privacy, the right to liberty is particularly important to constitutional text and tradition. The content and importance of this constitutional trajectory-from privacy to liberty-is the focus of the present section. So far, the Court has not made a similar turn to liberty in the Fourth Amendment context, despite the frequency in which it is called upon to balance the interests of security and liberty, ${ }^{30}$ and despite the existence of constitutional space to protect much more than privacy narrowly construed. As the following sections argue, Fourth Amendment jurisprudence should follow a similar trajectory-from privacy to liberty-especially regarding the protection of intimate and interpersonal relations as Laurence $v$. Texas suggests.

\section{A. Privacy as Personal}

Through a line of cases going back over half a century, the Supreme Court has developed the intertwined ideas of liberty and privacy as protecting a realm of human life free from government intrusion. Relying on the Due Process Clause of the Fourteenth Amendment, the Supreme Court protected the rights to conceive and raise one's own children, in important respects, free from government interference. ${ }^{31}$ During this same period, the Court also relied

30. See Hamdi v. Rumsfeld, 542 U.S. 507, 530-31 (2004) (balancing security and liberty). See also the Fourth Amendment "special needs" cases, beginning with New Jersey v. T.L.O., 469 U.S. 325, 351 (1985) (Blackmun, J., concurring) ("Only in those exceptional circumstances in which special needs, beyond the normal need for law enforcement, make the warrant and probablecause requirement impracticable, is a court entitled to substitute its balancing of interests for that of the Framers."), as well as Vernomia Sch. Dist. v. Acton, 515 U.S. 646, 653-54 (1995) (finding a special need for student athlete drug testing), Mich. Dep't of State Police v. Sitz, 496 U.S. 444, 455 (1990) (finding a special need for highway sobriety checkpoints), and MacWade v. Kelly, 460 F.3d 260, 271 ( $2 \mathrm{~d} \mathrm{Cir.} \mathrm{2006)} \mathrm{(upholding} \mathrm{random} \mathrm{subway} \mathrm{bag} \mathrm{searches} \mathrm{because} \mathrm{"preventing} \mathrm{a} \mathrm{terrorist} \mathrm{from} \mathrm{bombing}$ the subways constitutes a special need").

31. See Stanley v. Illinois, 405 U.S. 645 (1972); Pierce v. Soc'y of Sisters, 268 U.S. 510 (1925); Meyer v. Nebraska, 262 U.S. 390 (1923). 
on the Equal Protection Clause to protect rights relating to marriage, procreation, and family from laws that differentially impacted personal choices about how to live in meaningful relationships with others. ${ }^{32}$ The interlocking protections provided by the Due Process and Equal Protection clauses were articulated beginning with Griswold $\nu$. Connecticut ${ }^{33}$ as protections of the right to privacy. ${ }^{34}$

Holding that Connecticut could not criminalize the use of contraceptives by married couples, the Griswold Court reasoned that specific constitutional guarantees create "zones of privacy," or "area[s] of protected freedom" into which government may not intrude. ${ }^{35}$ Drawing on the "penumbras" and "emanations" from other specific Bill of Rights guarantees such as the protection "of the sanctity of a man's home and the privacies of life" under the Fourth and Fifth Amendments, the Court protected the intimate association of the marital relationship in the absence of a single, textually explicit provision on which it could base its opinion. ${ }^{37}$ The right of association is a "peripheral First Amendment right," the Court noted, that protects "the freedom to associate and privacy in one's associations," ${ }^{38}$ including the relation of marriage. Because "privacy surround[s] the marriage relationship," government cannot intrude into the sanctity of this interpersonal association without exceedingly compelling reasons. Important as the right to privacy in one's associations may be, marriage is not just any association, because it "is an association that promotes a way of life," according to Justice Douglas writing in Griswold, and constitutes "a harmony in living" with "bilateral loyalty.",39 Although Griswold struck down a law forbidding the use of contraceptives as having a "destructive impact" on the marital relation, later decisions broadened the "zone

32. See Loving v. Virginia, 388 U.S. 1 (1967) (invalidating a law criminalizing interracial marriage as violating equal protection); Skinner v. Oklahoma, 316 U.S. 535 (1942) (holding that, under equal protection, forced sterilization of convicted felons was unconstitutional).

33. 381 U.S. 479 (1965).

34. See id. In Laurence $v$. Texas, Justice Kennedy emphasizes the interlocking nature of due process and equality. He writes, "Equality of treatment and the due process right to demand respect for conduct protected by the substantive guarantee of liberty are linked in important respects, and a decision on the latter point advances both interests." 539 U.S. 558, 575 (2003); see also Laurence H. Tribe, Lawrence v. Texas: The 'Fundamental Right' That Dare Not Speak Its Name, 117 HARV. L. REV. 1893, 1902-07 (2004) (discussing the Supreme Court's blending of due process and equality).

35. Griswold, 381 U.S. at 485.

36. Boyd v. United States, 116 U.S. 616, 630 (1886).

37. The indirect complexity of the Court's rationale was at least partially caused by the Court's desire to avoid the ill-reputed notion of Substantive Due Process derived from Lochner v. New York, 198 U.S. 45 (1905), and repudiated in cases starting with West Coast Hotel Co. v. Parrish, 300 U.S. 379 (1937), and United States v. Carolene Products Co., 304 U.S. 144 (1938).

38. Griswold, 381 U.S. at 483 (citing NAACP v. Alabama, 357 U.S. 449, 462 (1958)).

39. Id. at 486 . 
of privacy" to extend to other personal relations that may involve questions of sex and its potential consequences. ${ }^{40}$ Despite the language focusing on the right of the individual to be free from unwanted government intrusion in Eisenstadt v. Baird, ${ }^{41}$ which extended the protection for the use of contraceptives to nonmarried persons, the right of privacy was not something exercised in isolation from other persons. Marriage, child rearing, and the need for contraception all involve interpersonal associations with others.

Consequences of heterosexual relationships disproportionately fall on women, who must bear the burden of choosing how to organize and shape their lives in light of a pregnancy. ${ }^{42}$ After the Court's recognition that privacy protects choices related to marriage and procreation, it was only a small, albeit monumentally important, step to recognize privacy's protection for a woman's choice to terminate her pregnancy. Privacy became the linchpin of the Court's opinion in Roe v. Wade." As Justice Blackmun wrote, "[t]his right of privacy ... is broad enough to encompass a woman's decision whether or not to terminate her pregnancy." ${ }^{44}$ What has created enduring controversy over the articulation and application of a right to privacy is its textual status. ${ }^{45}$ Justice Blackmun, writing in Roe, followed a similar scatter-shot method to the one Justice Douglas employed in Griswold, noting that "[ $\mathrm{t}]$ he Constitution

40. See Carey v. Population Servs. Int'l, 431 U.S. 678, 687 (1977) ("[T]he Constitution protects individual decisions in matters of childbearing from unjustified intrusion by the State."); Eisenstadt v. Baird, 405 U.S. 438, 453 (1972) ("If the right of privacy means anything, it is the right of the individual, married or single, to be free from unwarranted governmental intrusion into matters so fundamentally affecting a person as the decision whether to bear or beget a child.").

41. Eisenstadt, 405 U.S. at 453.

42. On the idea that the issue of choice related to pregnancy is one of equality, see Ruth Bader Ginsburg, Some Thoughts on Autonomy and Equality in Relation to Roe v. Wade, 63 N.C. L. REV. 375 (1985).

43. 410 U.S. 113 (1973).

44. Id. at 153 .

45. As Louis Henkin put it, "[w] hat we do not know with confidence are the determinants of that zone of privacy, or the principle of inclusion within it." Louis Henkin, Privacy and Autonomy, 74 COLUM. L. REV. 1410, 1423 (1974). This method of recognizing overlapping "zones of privacy" throughout the Bill of Rights has been subjected to withering criticism. See, e.g., John Hart Ely, The Wages of Crying Wolf: A Comment on Roe v. Wade, 82 YALE L.J. 920, 947 (1973) ("[It] is bad because it is bad constitutional law, or rather because it is not constitutional law and gives almost no sense of an obligation to try to be"). Additional criticisms include Geoffrey C. Hazard, Jr., Rising Above Principle, 135 U. PA. L. REV. 153, 166 (1986) ("Roe is justly subject to criticism on grounds of legitimacy ... because it can fairly be said that it went too far beyond precedent. Roe tried to effectuate through the medium of a single judicial decision a greater change in the law than is permitted under our constitutional system."), and Andrew Koppelman, Forced Labor: A Thirteenth Amendment Defense of Abortion, 84 Nw. U. L. REV. 480, 480 (1990) ("Roe v. Wade is an unpersuasive opinion, and the root of its unpersuasiveness is the Supreme Court's failure to ground its decision, that abortion is a fundamental right, in the text of the Constitution." (footnote omitted)). 
does not explicitly mention any right of privacy, ${ }^{, 46}$ though it appears in different guises in several constitutional provisions. ${ }^{47}$

Ultimately, the Court expressed in Roe its belief that the right of privacy is "founded in the Fourteenth Amendment's concept of personal liberty." ${ }^{\wedge 8}$ As if to underscore the importance of that founding, after several cases considering various ways in which a woman's right to choose to end her pregnancy could be regulated by the State, ${ }^{49}$ Justices O'Connor, Kennedy, and Souter began and ended their joint opinion in Planned Parenthood $v$. Casey ${ }^{50}$ with the word "liberty." a woman's fundamental right to shape key aspects of her life, the joint opinion emphasized the fact that "[i]t is a promise of the Constitution that there is a realm of personal liberty which the government may not enter.,"52 As if to accept the invitation to read the Bill of Rights as a Constitution, ${ }^{53}$ the Court focused on liberty, both as a right specifically guaranteed by the Fifth and Fourteenth Amendments, and as a right more broadly construed as a "promise of the Constitution."

We learn much more about the shape and content of this liberty right from the joint opinion's discussion of precedents each addressing deeply personal matters. Each precedent

involv[ed] the most intimate and personal choices a person may make in a lifetime, choices central to personal dignity and autonomy, are central to the liberty protected by the Fourteenth Amendment. At the heart of liberty is the right to define one's own concept of existence, of meaning, of the universe, and of the mystery of human life. ${ }^{54}$

The joint opinion, while grounded in protections afforded the interpersonal relations of marriage, family, child rearing, and education, struck a decidedly more individualist chord, focusing as it did on the "explication of individual

46. Roe, 410 U.S. at 152 .

47. The relevant provisions include the First, Fourth, Fifth, and Ninth Amendments, as well as the liberty guaranteed by the Fourteenth Amendment. Id. at 152-53.

48. Id. at 153.

49. See Webster v. Reprod. Health Servs., 492 U.S. 490 (1989); Thornburgh v. Am. Coll. of Obstetricians \& Gynecologists, 476 U.S. 747 (1986); City of Akron v. Akron Ctr. for Reprod. Health, 462 U.S. 416 (1983); Planned Parenthood of Cent. Mo. v. Danforth, 428 U.S. 52 (1976).

50. 505 U.S. $833(1992)$.

51. Id. at 844,901 .

52. Id. at 847 (emphasis added).

53. Akhil Reed Amar, The Bill of Rights as a Constitution, 100 YALE L.J. 1131, 1131 (1991) ("Instead of being studied holistically, the Bill has been chopped up into discrete chunks of text with each bit examined in isolation.").

54. Casey, 505 U.S. at 851. 
liberty." W5 Where the State would insist on "its own vision of the woman's role, ${ }^{, 56}$ women, the Court concluded, must have liberty to envision their own lives and their own place in society. ${ }^{57}$ Choices about how to live our lives, when these choices are about intimate and personal matters, shape the meaning and purpose of our everyday life projects. Self-direction in defining the parameters of one's own life, the Court instructs, is at the heart of liberty. ${ }^{58}$

It may be true that liberty protects self-determination, but this does not necessarily mean that the Court has always protected the liberty to engage in acts deemed by some to be morally objectionable or ambiguous. ${ }^{59}$ As if to follow the Court's antiprivacy rationale in Bowers v. Hardwick, ${ }^{60}$ the Casey Court did note that "[a]bortion is a unique act." ${ }^{161}$ In Bowers, the Court had construed a challenge to a law criminalizing the act of sodomy as a question of "whether the Federal Constitution confers a fundamental right upon homosexuals to engage in sodomy." ${ }^{, 62}$ By focusing only on the State's regulation of the sexual act, the Bowers majority ignored any dignitary harms created by criminalizing homosexual sodomy. As a consequence, the Court did not perceive the interpersonal act as having a formative meaning in the lives of individuals at liberty to choose to engage in the act. ${ }^{63}$ Since it did not recognize how intimate acts intertwine with personal lives and relationships, the Bowers Court did not consider privacy as a limit on government intrusion. By contrast, the Casey Court complicated its focus on the act of abortion by suggesting that it is one "fraught with consequences for others," acknowledging

55. Id. at 853 .

56. Id. at 852 .

57. On the importance of developing constitutional vision, see Thomas P. Crocker, Envisioning the Constitution, 57 AM. U. L. REV. 1 (2007).

58. Casey, 505 U.S. at 851.

59. For some there is no ambiguity in the Court's decision to protect a woman's right to make choices regarding her pregnancy. See, e.g., Steven G. Calabresi, How to Reverse Government Imposition of Immorality: A Strategy for Eroding Roe v. Wade, 31 HARV. J.L. \& PUB. POL'Y 85, 85 (2008) ("Roe v. Wade was... not merely wrongly decided. It was also profoundly immoral.").

60. 478 U.S. $186(1986)$.

61. Casey, 505 U.S. at 852.

62. 478 U.S. at 190.

63. In dissent, Justice Blackmun argued that the majority was indeed blind to the facts and implications of both precedent and the current case. He wrote, "Only the most willful blindness could obscure the fact that sexual intimacy is 'a sensitive, key relationship of human existence."' Id. at 205 (Blackmun, J., dissenting) (quoting Paris Adult Theatre I v. Slaton, 415 U.S. 49, 63 (1973)). Furthermore, the majority's unwillingness to see the principle animating the Court's precedent was possible only by "clos[ing] our eyes to the basic reasons why certain rights associated with the family have been accorded shelter under the Fourteenth Amendment's Due Process Clause." Id. at 204 (quoting Moore v. City of East Cleveland, 431 U.S. 494, 501 (1977)). 
the fact that a woman's choice involves and implicates other people. ${ }^{64}$ Privacy in making fundamental decisions about the course of one's life is not an isolated value. It marks a site of deep division over what matters are of public concern and what matters are beyond government determination, even if they are not matters that involve the person claiming privacy alone.

Privacy, as a separate analytic category in Casey, faded back into the liberty right from whence it in part emerged. One way of understanding the textual indeterminacy of privacy is that it delimits an area of personal liberty involving choices about personal, not public, matters. When the State determines whether one can marry a person of a different race, ${ }^{65}$ or whether certain people can get married at all, ${ }^{66}$ or whether a parent can teach her child German, ${ }^{67}$ or whether an individual may use contraceptives, ${ }^{68}$ the State converts personal decisions about how individuals wish to conduct their lives into public matters. Public matters are ones about which government may set standards and rules applicable to everyone, irrespective of particular circumstances, or individual wishes. Private choices become public matters only when they create unwanted social costs or implicate public values. In a pluralistic society, these values will be contested, as will the legitimate boundaries between what is private and what is public. By protecting a constitutional right to privacy applicable to decisions sometimes affecting contested values, the Court distinguishes between choices that are properly personal from those that are legitimately public. In marking this distinction with the concept of privacy, the Casey Court sought to preserve "a realm of personal liberty which the government may not enter. ${ }^{169}$ As this section has indicated, "privacy" does not uniquely protect acts that are merely personal, but often involves acts and relations that are deeply interpersonal. In moving from privacy to liberty, the Casey Court acknowledged the importance of interpersonal relations, the value of which extends beyond the narrow confines of privacy as individual and undisclosed.

64. Casey, 505 U.S. at 852 (recognizing consequences "for the woman ... for the persons who perform and assist in the procedure; for the spouse, family, and society ... for the life or potential life that is aborted").

65. See Loving v. Virginia, 388 U.S. 1 (1967).

66. See Turner v. Safley, 482 U.S. 78 (1987); Zablocki v. Redhail, 434 U.S. 374 (1978).

67. See Meyer v. Nebraska, 262 U.S. 390 (1923).

68. See Eisenstadt v. Baird, 405 U.S. 438, 453 (1972); Griswold v. Connecticut, 381 U.S. 479 (1965).

69. Casey, 505 U.S. at 847 (emphasis added). 


\section{B. Liberty as Interpersonal}

In Laurence $v$. Texas, ${ }^{70}$ the Court issued a resounding opinion recognizing that gays and lesbians have the "right to liberty under the Due Process Clause" to live free from state intrusion into their personal and private lives. ${ }^{11}$ Articulating the central object protected by privacy as "spheres of our lives" involving "liberty of the person" without grounding his reasoning specifically on the concept of privacy, Justice Kennedy, writing for the majority, began the opinion:

Liberty protects the person from unwarranted government intrusions into a dwelling or other private places. In our tradition the State is not omnipresent in the home. And there are other spheres of our lives and existence, outside the home, where the State should not be a dominant presence. Freedom extends beyond spatial bounds. Liberty presumes an autonomy of self that includes freedom of thought, belief, expression, and certain intimate conduct. The instant case involves liberty of the person both in its spatial and in its more transcendent dimensions. ${ }^{72}$

Laurence involved a state statute criminalizing homosexual sodomy. Almost as if in response to Griswold v. Connecticut's ${ }^{73}$ hypothetical question as to whether we would "allow the police to search the sacred precincts of marital bedrooms, ${ }^{74}$ officers of the Harris County Police Department entered John Geddes Lawrence's apartment and found him engaged in a sex act with another man. ${ }^{75}$ Here, the facts involved no marriage, and no recognition of a sacred precinct, yet the intrusion into the privacy of a dwelling and the interference with a sphere of Mr. Lawrence's life are no less significant. The facts of this case also illustrate both domains in which liberty operates: the home, or "the spatial," and the personal, or "more transcendent dimensions." Both dimensions of liberty establish a prohibition against the government becoming a dominant presence in our lives.

Despite the fact that the bedroom invaded was not the marital bedroom, the Court nonetheless recognized that the State's actions implicated a personal relationship. "The statutes do seek to control a personal relationship that, whether or not entitled to formal recognition in the law, is within the liberty

70. 539 U.S. $558(2003)$.

71. Id. at 578 .

72. Id. at 562 .

73. 381 U.S. 479.

74. Id. at 485 .

75. Laurence, 539 U.S. at 562-63; see also Dale Carpenter, The Unknoun Past of Lawrence v. Texas, 102 MICH. L. REV. 1464 (2004) (investigating the factual circumstances of the Laurence case). 
of persons to choose without being punished as criminals." ${ }^{.76}$ Moreover, the State's statute and actions touch "upon the most private human conduct, sexual behavior, and in the most private of places, the home."77 Thus, we have the interweaving of the two, often separate strands of privacy: the personal and the home. Both are conceived, not entirely as sites of individual isolation, but as places in which one shares intimacies with others. With whom one shares intimacies, and how those intimacies are expressed within a private sphere of life, are not proper matters for governmental regulation. Of course, the quick response from Justice Scalia in dissent is that such a claim calls into question all manner of public morals legislation involving prostitution, gay marriage, adultery, fornication, and obscenity. Indeed, some, perhaps all, of this kind of legislation is in doubt in the wake of Laurence. ${ }^{78}$ The point, however, is not to designate which acts are now permissible and which are not, for that persists in thinking that Laurence is only about regulation of a particular sex act. Rather, Laurence is more importantly about a sphere of interpersonal relations that are constitutive of particular forms of everyday life that government may not itself define. ${ }^{79}$

In moving back and forth between a statement of liberty as autonomy and liberty as interpersonal, the Lawrence Court recognized the status-definitional implications of criminalizing not just sexual acts, but also everyday ways of living and relating to others. In this light, the Laurence Court concluded that the harm wrought by the prohibition against sodomy was the stigmatization of intimate personal relations. ${ }^{80}$ The Court claimed that "[t]o say that the issue

76. Laurence, 539 U.S. at 567.

77. Id.

78. Id. at 590 (Scalia, J., dissenting); see also Cass R. Sunstein, Liberty After Lawrence, 65 OHIO ST. L.J. 1059 (2004) (discussing Laurence's implications for various forms of sex, marital and employment regulations); Cass R. Sunstein, What Did Lawrence Hold? Of Autonomy, Desuetude, Sexuality, and Marriage, 2003 SUP. CT. REV. 27 (same).

Under state constitutional provisions, state barriers to gay marriage have been struck down in Goodridge v. Dep't of Pub. Health, 798 N.E.2d 941 (Mass. 2003), In re Marriage Cases, 183 P.3d 384 (Cal. 2008), and Varnum v. Brien, 763 N.W.2d 862 (lowa 2009). Challenges to the Defense of Marriage Act are pending. See Abby Goodnough \& Katie Zezima, Suit Seeks to Force Government to Extend Benefits to Same-Sex Couples, N.Y. TIMES, Mar. 3, 2009, at A12.

79. I have in mind here something more comprehensive when referring to ordinary or everyday life. Charles Taylor explains: "'Ordinary life' is a term of art I introduce to designate those aspects of human life concerned with production and reproduction, that is, labour, the making of the things needed for life, and our life as sexual beings, including marriage and the family." CHARLES TAYLOR, SOURCES OF THE SELF: THE MAKING OF THE MODERN IDENTITY 211 (1989). Some of the practices of ordinary life are both more central to personal notions of meaning and more private insofar as they encompass aspects of life shared with increasingly fewer persons as we move inward from communities and friends, to extended family units, to the marital relation itself.

80. Laurence, 539 U.S. at 575 ("The stigma this criminal statute imposes, moreover, is not trivial."). 
in Bowers was simply the right to engage in certain sexual conduct demeans the claim the individual put forward, just as it would demean a married couple were it to be said that marriage is simply about the right to have sexual intercourse." ${ }^{, 81}$ In so claiming, the Court emphasized the importance of the relationship as transcending the physical acts that may accompany it. Suggestions otherwise, to make the interpersonal act the defining feature of the relationship, fail to understand the vital role the relationship itself plays in the lives of the individuals whose liberty is implicated. To reduce the meaning of interpersonal relations to the mere performing of sex acts is to reduce the realm of human expression to the domain of physical bodies in motion. We are embodied beings, but we are not simply bodies who act; rather, physical acts in the presence of or in contact with other persons help define the worlds we inhabit. When interpersonal physical contact is "within the liberty of persons to choose" in pursuing their own conceptions of everyday human life, then they may fulfill the interpersonal relationship "without being punished as criminals." ${ }^{82}$

Opposing the notion that the State may control the meaning, role, and place of personal relationships in our everyday moral lives, the Court explained: "When sexuality finds overt expression in intimate conduct with another person, the conduct can be but one element in a personal bond that is more enduring." ${ }^{\prime 83}$ What is at issue is not the ability to engage in a physical act, as Justice Scalia's dissent emphasizes ${ }^{84}$ and the majority in Bowers argued, ${ }^{85}$ but the ability of self-defining persons to have a particular kind of relationship. Government cannot "define the meaning of the relationship or to set its boundaries absent injury to a person or abuse of an institution the law protects. ${ }^{, 86}$ We live our everyday lives in the company of others, sometimes in intimate relations, sometimes in more impersonal social and business relations, and often somewhere in between. The more intimate the relation, the more it plays a role in defining who we are. When we form enduring personal bonds in association with others, we do so in fulfillment of everyday life projects that are constitutive of personal and interpersonal liberty.

81. Id. at 567 .

82. Id.

83. Id.

84. See id. at 594 (Scalia, J., dissenting) ("Not once does [the Court] describe homosexual sodomy as a 'fundamental right' or a 'fundamental liberty interest."').

85. See Bowers v. Hardwick, 478 U.S. 186, 191 (1986) (framing the issue as involving "a fundamental right to engage in homosexual sodomy").

86. Laurence, 539 U.S. at 567. 
Interpersonal relationships find protection in other applications of the "liberty protected by the Constitution." ${ }^{87}$ For example, the Supreme Court protects some personal relationships through First Amendment freedom of association. When government controls or dictates the terms of our personal relations or forces inclusion of unwanted persons into our group associations, it violates a realm of protected freedom "to advocate public or private viewpoints," ${ }^{, 88}$ and "interferes with individuals' selection of those with whom they wish to join in a common endeavor. ${ }^{399}$ In Roberts $v$. Jaycees, ${ }^{90}$ the Court considered how the forced inclusion of women into a male-only organization might affect the organization's members' freedom of intimate and expressive association. The Court noted "that certain kinds of personal bonds have played a critical role in the culture and traditions of the Nation," and by so doing, these bonds "act as critical buffers between the individual and the power of the State."191 Citing cases protecting due process liberty rights, the Court recognized the role that interpersonal relationships play in providing "emotional enrichment," and "the ability independently to define one's identity that is central to any concept of liberty." as part of what it means to be human, and part of what it means to form a community. Everyday life is inescapably lived in the company and with the cooperation of others. Even though "the Bill of Rights is designed to secure individual liberty," the Court recognized that "it must afford the formation and preservation of certain kinds of highly personal relationships a substantial measure of sanctuary from unjustified interference by the State. ${ }^{.93}$ As the Roberts Court recognized, individual liberty is inseparable from the "highly personal relationships" on which it depends, and thus individual liberty is not liberty in isolation from all others persons. ${ }^{94}$

If we view Laurence alongside Roberts, we see that interpersonal relations play a significant role in safeguarding personal liberty in multiple settings-from a personal decision that implicates others in Casey, to the intimate relations

87. Id.

88. Boy Scouts of Am. v. Dale, 530 U.S. 640, 648 (2000).

89. Roberts v. U.S. Jaycees, 468 U.S. 609,618 (1984).

90. Id.

91. Id. at 618-19.

92. Id. at 619 .

93. Id. at 618 .

94. Regarding liberty, the Court has recognized the importance of interpersonal relations. Regarding equality, the Court has often rejected the importance of group identity. Regarding equal protection, Justice O'Connor claimed that the Constitution "protect[s] persons, not groups." Adarand Constructors, Inc. v. Pena, 515 U.S. 200, 227 (1995). Liberty protections for associations and intimacy involve far more personal and interpersonal relations than the relations that exist merely on the basis of a group classification according to characteristics such as race or gender. 
at stake in criminalization of sodomy, to the expression of ideals and beliefs at issue in regulating associations. Liberty is not limited to individuals whose lives are complete only when secreted away from all others, and liberty protects more than particular actions or behaviors. Because liberty creates a "zone of privacy" shared and experienced with others, we see the Court preserving a sanctuary in which individuals may live in relationships with others free from interference by the State. ${ }^{95}$

There is no small amount of irony, in light of Laurence, in the Court's protecting the Boy Scouts of America's right to associate for the partial purpose of expressing a strictly heterosexual normative ideal. In Boy Scouts of America v. Dale, ${ }^{96}$ the Court considered whether James Dale, a former Eagle Scout and also a gay man, "would significantly burden the Boy Scouts' desire to not promote homosexual conduct as a legitimate form of behavior." Although the Court was fixated again on the approval or disapproval of particular conduct, the Court protected the right of the group "not to propound a point of view contrary to its beliefs." Why is this expression of particular beliefs important? The Court does not fully explain, but relies instead on the notion that if a group's identity is partly defined by its views, then the freedom to associate allows exclusion of others who do not share those views. ${ }^{99}$ In so doing, the Court went beyond protecting the ability to associate for the purpose of advancing beliefs and ideas, in order to protect the integrity and dignity of the association as it projects its identity into the world. ${ }^{100}$ Public identity is manifest through the content of the expressive association of individuals who share common ideals and beliefs. Thus, the State may not require a group to include a member who "would significantly burden the

95. Limitations on state interference may even apply to the military's Don't Ask, Don't Tell policy. The Ninth Circuit held that "[w]hen the government attempts to intrude upon the personal and private lives of homosexuals, in a manner that implicates the rights identified in Laurence," it must justify its intrusion to satisfy a heightened standard of judicial review. Witt v. Dep't of the Air Force, 527 F.3d 806, 819 (9th Cir. 2008).

96. 530 U.S. $640(2000)$.

97. Id. at 653 .

98. Id. at 654 .

99. The problem with this reasoning is that all racist or misogynist employers want to exclude others as part of the expression of their views. See Jed Rubenfeld, The First Amendment's Purpose, 53 STAN. L. REV. 767 (2001).

100. The more limited view of associational rights is expressed: "[T]he First and Fourteenth Amendments protect certain forms of orderly group activity. Thus we have affirmed the right 'to engage in association for the advancement of beliefs and ideas."' NAACP v. Button, 371 U.S. 415, 430 (1963) (quoting NAACP v. Alabama, 357 U.S. 449, 460 (1958)); see also NAACP v. Alabama, 357 U.S. at 460 ("It is beyond debate that freedom to engage in association for the advancement of beliefs and ideas is an inseparable aspect of the 'liberty' assured by the Due Process Clause of the Fourteenth Amendment, which embraces freedom of speech."). 
organization's right to oppose or disfavor homosexual conduct"101 by his mere presence in the organization. ${ }^{102}$

What is interesting here is that from the perspective of protecting the status of homosexual persons, Laurence and Dale pull in opposite directions. But from the perspective of protecting our right to define our identities, they are of a piece. The intimate association in Laurence, as defining the participants' individual identities, and the social association in Dale, as defining the group's expressive identity, are both protected. Both are situations in which the government may not legitimately interfere, because to do so would be to dictate the content of the message or the character of the relationship. Laurence and Dale both protect the ability to define through conduct and expression core aspects of life, free from laws functioning as "severe intrusion[s] $]^{1103}$ that would subject the individual or group to homogenizing constraints. ${ }^{104}$ Finally, both decisions avoid analytically relying on the concept of privacy, opting instead for liberty and First Amendment freedom of expression, respectively.

Laurence, Roberts, and Dale are all cases protecting different kinds of interpersonal relationships that are both expressive and identity definitional. Although we could describe each as protecting a form of privacy-a realm of personal life free from government interference-we see the Court protecting each as forms of liberty through the Due Process Clause and the First Amendment. Rather than relying on a narrow understanding of privacy as personal and individual, the Court protects liberty as interpersonal, recognizing the importance of intimate and personal bonds persons have with each other. To foreshadow the developing argument, this interpersonal aspect of liberty provides the basis for reorienting the Fourth Amendment's narrow focus on privacy as personal..$^{105}$

101. Dale, 530 U.S. at 659.

102. Such reasoning implies that the group as a group has a single view on homosexuality that would be severely burdened in the same way that an individual would be burdened to adopt views she did not hold. But the facts do not support this proposition, for no doubt there existed internal dissent and difference nationally over this very issue of including gay members. See Madhavi Sunder, Cultural Dissent, 54 STAN. L. REV. 495, 508 (2001) ("[T] he Court ignored internal dissent in the Scouts over homosexuality and treated Boy Scouts culture like a 'thing' that is static, homogeneous, bounded, and distinct.").

103. Dale, 530 U.S. at 659.

104. Jamal Greene argues that the Court in both Dale and Laurence protects what he calls "metaprivacy," "the right to engage in status-definitional conduct free from normalizing governmental interference." Jamal Greene, Beyond Lawrence: Metaprivacy and Punishment, 115 YALE L.J. 1862, 1875 (2006). The right to shed governmentally imposed stigma is an important due process development. "Themes of respect and stigma are at the moral center of the Laurence opinion, and they are entirely new to substantive due process doctrine." Robert C. Post, Foreword: Fashioning the Legal Constitution: Culture, Courts, and Law, 117 HARV. L. REV. 4, 97 (2003).

105. See infra Part IV. 


\section{Autonomy, Intimacy, and Dignity: The Interpersonal Values of Liberty and Privacy}

Due process jurisprudence is often tethered to tradition ${ }^{106}$ and protective of "choices central to personal dignity and autonomy." Autonomy over particular choices can be construed as matters of personhood considered independently from other persons. ${ }^{108}$ Autonomy is particularly implicated by "the ability independently to define one's identity that is central to any concept of liberty,"109 as Justice Blackmun's Bowers dissent emphasizes. Nonetheless, as Parts I.A and I.B demonstrated, the context of autonomous decisions about such matters as family, childbirth, and intimate associations all involve relations to other persons, even if status-definitional considerations are at issue that implicate the dignity of persons. Dignity requires respect for socially embedded persons whose status and identity depend on the attitudes of other individuals and of governing institutions. If " $[\mathrm{f}]$ reedom extends beyond [the] spatial bounds" 110 of household privacy, as Laurence claims, then freedom should also encompass social structures in which attitudes of mutual respect reign. ${ }^{111}$ Within these social structures, interpersonal relations also centrally involve matters of intimacy encompassing not only the ability to share or withhold informational and social aspects of life from other persons, but also the capacity to share or withhold bodily contact with others. When the Constitution is thought to protect "a certain private sphere of individual liberty," 12 we are tempted to consider the core value in personal terms only. Rejecting this temptation, the following sections argue that autonomy, intimacy, and dignity are all also interpersonal values protected under due process.

106. See, e.g., Washington v. Glucksberg, 521 U.S. 707 (1997); Cruzan v. Dir., Mo. Dep't of Health, 497 U.S. 261 (1990).

107. Planned Parenthood of Se. Pa. v. Casey, 505 U.S. 833, 851 (1992).

108. Laurence acknowledges the importance of "the respect the Constitution demands for the autonomy of the person in making these choices." Lawrence v. Texas, 539 U.S. 558, 574 (2003).

109. Bowers v. Hardwick, 478 U.S. 186, 205 (1986) (Blackmun, J., dissenting) (quoting Roberts v. U.S. Jaycees, 468 U.S. 609,619 (1984)).

110. Lawrence, 539 U.S. at 562.

111. See Robert C. Post, Three Concepts of Privacy, 89 GEO. L.J. 2087, 2092 (2001) ("To equate privacy with dignity is to ground privacy in social forms of respect that we owe each other as members of a common community."); James Q. Whitman, The Two Western Culures of Privacy: Dignity Versus Liberty, 113 YaLE L.J. 1151, 1214 (2004).

112. Thomburgh v. Am. Coll. of Obstetricians \& Gynecologists, 476 U.S. 747, 772 (1986). 


\section{Autonomy}

These cases protecting individual, interpersonal, and associational liberty can be read to advance a core interest in decisional and expressive autonomy. From privacy's origin in protecting personal decisions about sex and childbirth, to Laurence's emphasis on the liberty to choose with whom to engage in intimate conduct, to Dale's preserving a right to control the expressive "message" an association chooses to project to the world, a core interest in autonomy is undoubtedly often at stake. In the academy, this view has often held sway, ${ }^{113}$ aided by language in the Court's cases indicating a strong solicitude for protecting the autonomy of choice. ${ }^{114}$ Some applications of Laurence emphasize the autonomous independence of individual, private conduct. The Fifth Circuit, for example, applied Laurence to hold that a Texas state law criminalizing the sale and promotion of sexual devices violates an individual's right to engage in private intimate conduct. ${ }^{115}$ Because autonomy is a value that vindicates independence from other individuals, autonomy could be understood to undercut the importance the Court places on personal relations as necessary and sacrosanct aspects of liberty. To do so, however, would require us to ignore the repeated emphasis the Court places on personal liberty's dependence on relationships with others.

Autonomy, understood through the lens of privacy, can take different forms-the desire "to be let alone,"116 the ability to withhold information from others, the will to maintain secrecy, or the choice to enter into intimate relations with others. ${ }^{17}$ The "right to be let alone" is the most general formula-

113. See, e.g., Louis Henkin, Privacy and Autonomy, 74 ColuM. L. Rev. 1410, 1425 (1974) ("Primarily and principally the new Right of Privacy is a zone of prima facie autonomy.").

114. Even Laurence recognizes "the respect the Constitution demands for the autonomy of the person in making [particular] choices," Laurence, 539 U.S. at 574, following Casey's emphasis that "[t]hese matters, involving the most intimate and persona choices a person may make in a lifetime ...." Planned Parenthood of Se. Pa. v. Casey, 505 U.S. 833, 851 (1992).

115. Reliable Consultants, Inc. v. Earle, 517 F.3d 738, 746 (5th Cir. 2008) ("The case ... is about controlling what people do in the privacy of their own homes because the State is morally opposed to a certain type of consensual private intimate conduct. This is an insufficient justification for the statute after Laurence."). But see Williams v. Att'y Gen. of Ala., 378 F.3d 1232 (11th Cir. 2004) (holding that an Alabama anti-obscenity statute prohibiting the sale of sex toys does not violate a fundamental right under Laurence).

116. The "right to be let alone" was first conceptualized by Samuel D. Warren \& Louis D. Brandeis, The Right to Privacy, 4 HARV. L. REV. 193, 193 (1890). Later Justice Brandeis articulated the right: "The makers of our Constitution . . . conferred, as against the Government, the right to be let alone-the most comprehensive of rights and the right most valued by civilized men." Olmstead v. United States, 277 U.S. 438, 478 (1928) (Brandeis, ]., dissenting).

117. Autonomy and privacy are concepts with multiple and overlapping meanings. See generally Solove, supra note 28. 
tion with the most distinguished pedigree. ${ }^{118}$ When government interferes with our daily life, whether by searching our person or belongings or by regulating personal aspects of our lives, it fails to respect an independent realm where we might be left alone to pursue our life projects. Another form of autonomy is an individual's strong interest in protecting certain matters from unauthorized access by others. ${ }^{119}$ In so doing, one preserves the ability to develop a distinct sense of personhood separate from and uncontrolled by others. Our identity can be a plurality, as we take up varying social roles, revealing different aspects of ourselves in relation to distinct groups and individuals. As William James has suggested, man has "as many different social selves as there are distinct groups of persons about whose opinion he cares. He generally shows a different side of himself to each of these different groups." ${ }^{120}$ When we withhold aspects of our lives from others and when they recognize and respect our choices to withhold certain matters as private, we experience the space to develop our own, plural identity. ${ }^{121}$ Taken to an extreme, privacy becomes the keeping of secrets. The Supreme Court has embraced this conception in the Fourth Amendment context, emphasizing that nondisclosure to others ensures that information about oneself "will remain secret."

More than ways of withholding information from others or of desiring to be let alone, autonomy is about making decisions on how to live one's life free from unwanted intrusion. "Put compendiously, the most basic autonomyright is the right to decide how one is to live one's life, in particular how to make the critical life decisions," which constitute the content of everyday life, as Joel Feinberg explains. ${ }^{123}$ This conception of decisional privacy is found most clearly in claims by the Court to protect the "most intimate and personal

118. See id. at 1099-102.

119. As Charles Fried suggests, "[p]rivacy is not simply an absence of information about us in the minds of others; rather it is the control we have over information about ourselves." Charles Fried, Privacy, 77 YALE L.J. 475, 482 (1968). Ruth Gavison also writes, "[a] loss of privacy occurs as others obtain information about an individual, pay attention to him, or gain access to him." Ruth Gavison, Privacy and the Limits of Law, 89 YALE L.J. 421,428 (1980).

120. William James, The Philosophy of William James: Selected From His Chief WORKS 128 (Horace M. Kallen, ed., The Modern Library 1953) (1925).

121. See Lawrence v. Texas, 539 U.S. 558, 562 (2003) (protecting "liberty of the person both in its spatial and in its more transcendent dimensions"); Planned Parenthood of Se. Pa. v. Casey, 505 U.S. 833, 851 (1992) (articulating the "right to define one's own concept of existence"). See generally ERVING GOFFMAN, THE PRESENTATION OF SELF IN EVER YDAY LIFE (1973).

122. Smith v. Maryland, 442 U.S. 735, 743 (1979).

123. Joel Feinberg, Autonomy, Sovereignty, and Privacy: Moral Ideals in the Constitution?, 58 NOTRE DAME L. REV. 445, 454 (1983). Feinberg enumerates some of the relevant life decisions as "what courses of study to take, what skills and virtues to cultivate, what career to enter, whom or whether to marry, which church if any to join, whether to have children, and so on." Id. 
choices a person may make in a lifetime." ${ }^{\text {"24 }}$ We chart our life course and develop ourselves as unique persons through the choices we make about how we want to live our everyday lives. Both of what Michael Sandel calls "old" and "new" privacy involve autonomous choices about what kinds of facts to keep undisclosed to others, which are intertwined with important decisions about how to live our lives. ${ }^{125}$

The decisions in Dale and Laurence focus on the ability of persons and groups to choose how to present themselves in public by controlling what they do in private. Without dwelling too long on the relation between privacy and autonomy, it seems clear that Dale and Laurence rest squarely amidst this tangled web, even if they do not rely explicitly on the concept of privacy. ${ }^{126}$ The conceptual complexity of privacy in its relation to autonomy lures us to think of privacy as applying to individuals in social isolation. Nonetheless, autonomy, like privacy, is also relational. It is experienced in relation to other persons through varying degrees of intimacy. Reading Laurence alongside Dale, as this Article does, allows us to see how the liberty interest in the self presentation of individuals and groups is not exhausted by autonomy of choice. As Laurence makes clear, "[l]iberty presumes an autonomy of self." ${ }^{27}$ This argument emphasizes the fact that liberty extends beyond the presumed autonomy of a self socially isolated from other persons.

\section{Intimacy}

In addition, more than protecting autonomy, privacy can also manifest itself as "control over information which enables us to maintain degrees of intimacy," as Charles Fried has influentially argued. ${ }^{128}$ Fried's view of privacy depends upon the kind of sharing that creates the possibility of intimacy. Intimacy requires sharing spaces, experiences, emotions, thoughts, information,

124. Casey, 505 U.S. at 851.

125. Sandel explains: "The new privacy protects a person's 'independence in making certain kinds of important decisions,' whereas the old privacy protects a person's interest 'in avoiding disclosure of personal matters."' Michael J. Sandel, Moral Argument and Liberal Toleration: Abortion and Homosexuality, 77 CAL. L. REv. 521, 524 (1989) (citing Whalen v. Roe, 429 U.S. 589, 599-600 (1977)). Both forms of privacy involve autonomous control over aspects of one's life.

126. The concept of privacy eludes definition, ranging over a number of different interests and values. Robert Post has lamented that "Ip]rivacy is a value so complex, so entangled in competing and contradictory dimensions, so engorged with various and distinct meanings, that I sometimes despair whether it can be usefully addressed at all." Post, supra note 111, at 2087. Moreover, Daniel Solove suggests that "[t]he difficulty in articulating what privacy is and why it is important has often made privacy law ineffective and blind to the larger purposes for which it must serve." See Solove, supra note 28 , at 1090.

127. Lawrence v. Texas, 539 U.S. 558, 562 (2003).

128. Fried, supra note 119 , at 485. 
and many other things with other persons. After all, one cannot be intimate with oneself. Privacy for Fried, as the ability to control information about oneself, is the necessary condition "for relationships which we would hardly be human if we had to do without - the relationships of love, friendship and trust." 29 This relational emphasis involves more than making autonomous choices, but by focusing on controlling information, makes privacy a transactional commodity. ${ }^{130}$ Sharing, for Fried, is thus not intrinsically valuable for its role in constituting an interpersonally shared form of life. Rather, privacy is instrumental for certain kinds of relationships that are themselves necessary for developing aspects of one's personhood. ${ }^{131}$ So much of our lives-from family to friends, to work, and to community-requires degrees of mutual sharing and reciprocal trust through which we develop a distinct personal identity. These instrumental uses of intimacy are consistent with the concerns in both Lawrence and Dale, but are by themselves incomplete. As Jeffrey Reiman argues, Fried's understanding of sharing is missing "the context of caring which makes the sharing of personal information significant." 132

In our everyday forms of life, we experience bonds of affection with those who matter most in our lives, encouraging them to open themselves up to us in relationships of mutual trust and care. ${ }^{133}$ We sustain our relationships of mutual care through sharing our lives, thereby opening ourselves to others in ways that leave us exposed. ${ }^{134}$ When we share, we leave the shell of isolated privacy to experience a form of privacy in the company of others. The company we keep ranges over many kinds of relationships, with varying de-

129. Id. at 484; see also James Rachels, Why Privacy Is Important, 4 PHIL. \& PUB. AFF. 323, 329 (1975) ("[B]ecause our ability to control who has access to us, and who knows what about us, allows us to maintain the variety of relationships with other people that we want to have, it is, I think, one of the most important reasons why we value privacy.").

130. Jeffrey Reiman describes this approach as "a market conception of personal intimacy," through which "[t]he reality of my intimacy with you is constituted not simply by the quality and intensity of what we share, but by its unavailability to others-in other words, by its scarcity." Jeffrey H. Reiman, Privacy, Intimacy, and Personhood, 6 PHIL. \& PUB. AFF. 26, 32 (1976).

131. As Ruth Gavison puts it: "Privacy also functions to promote liberty in ways that enhance the capacity of individuals to create and maintain human relations of different intensities. Privacy enables individuals to establish a plurality of roles and presentations to the world." Ruth Gavison, Privacy and the Limits of Law, 89 YALE L.J. 421, 450 (1980).

132. Reiman, supra note 130 , at 33 .

133. Axel Honneth, developing an intersubjective basis for morality built on the imperatives of mutual recognition, considers: "Through our acts of affection, we encourage another person to open himself or herself up to us emotionally in such a way that he or she is rendered so vulnerable as to deserve, instead of mere moral respect, all the benevolence we can muster." AXEL HONNETH, DISRESPECT: THE NORMATIVE FOUNDATIONS OF CRITICAL THEORY 178 (2007).

134. See, e.g., SUSAN MOLLER OKIN, JUSTICE, GENDER, AND THE FAMILY (1989); Robin West, Jurisprudence and Gender, 55 U. CHI. L. REV. 1, 19-21 (1988). 
grees of friendship and the intimacies friendship enables. ${ }^{135}$ As Ethan Leib argues, friendship "is especially indispensable to the kind of good life our society prizes: lives with deep private and personal connections." ${ }^{136}$

Friendship is no stranger to law. ${ }^{137}$ Law often frames the background structures within which friendships exist. By acknowledging the significance of a mutual bond formed through intimate conduct, the Laurence Court moves beyond protecting the decision to enter into a personal relationship. Laurence also protects the reciprocity intrinsic to "a personal bond that is more enduring." ${ }^{138}$ The Court focuses on the importance of the relationship at issue in the criminalization of conduct described as homosexual, intimate, and private. Thus, even if autonomy is a central feature of privacy, autonomous life is not life lived in isolation from others. ${ }^{139}$ Rather, individual lives derive their most enduring meaning through shared intimacy with other persons. Whether understood instrumentally or constitutively, interpersonal relations are both the occasion in cases like Laurence and Griswold v. Connecticut ${ }^{140}$ for the Court to protect liberty, and the object of its protections.

\section{Dignity and Embodiment}

Lost in the jurisprudential focus on the movement from privacy to liberty is the fact that John Geddes Lawrence and Tyron Garner were engaged in the sexual act of sodomy when arrested by police officers. The Laurence Court recognizes "the due process right to demand respect for conduct protected by the substantive guarantee of liberty,"141 in a context in which the conduct is sex. In important respects, sex is about being and having a body, often in relation to other persons. The Court recognizes that such bodily acts conducted

135. See Ethan J. Leib, Friendship \& the Law, 54 UCLA L. REV. 631, 665 (2007) (arguing that "[t]he law makes possible and structures friendships, whether it does so consciously or not"). See generally ARISTOTLE, NICOMACHEAN ETHICS books viii-ix (Terence Irwin trans., 1985); ALASDAIR MACINTYRE, AFTER VIRTUE 155 (2d ed. 1984) ("The type of friendship which Aristotle has in mind is that which embodies a shared recognition of and pursuit of a good. It is this sharing which is essential and primary to the constitution of any form of community, whether that of a household or that of a city.").

136. Leib, supra note 135 , at 654.

137. See id.; Ethan J. Leib, Friends as Fiduciaries, 86 WASH. U. L. REV. 665 (2009).

138. Lawrence v. Texas, 539 U.S. 558, 567 (2003).

139. Robert Post argues that when we dress up privacy in the language of autonomy, we "miss the plain fact that privacy is for us a living reality only because we enjoy a certain kind of communal existence." Robert C. Post, The Social Foundations of Privacy: Community and Self in the Common Law Tort, 77 CAL. L. REV. 957, 1010 (1989).

140. 381 U.S. 479 (1965).

141. Laurence, 539 U.S. at 575. 
with other persons form part of our "dignity as free persons."142 Being embodied implicates privacy because we reveal and conceal our bodies to others. It implicates autonomy because we ordinarily have control over our own bodies. But being embodied also implicates other persons.

Focusing on the conduct of individuals, as constitutive of particular social practices, highlights the degree to which the lives of embodied persons are at stake. We are embodied agents, acting and reacting to bodily stimuli in our environments. We have an upright posture that orients our perceptions of the world. ${ }^{143}$ As social psychologists suggest, our upright posture also constructs the ways we encounter and interact with other persons. ${ }^{144}$ Our interactions with others are always at varying physical distances, and change given the degree of familiarity and reciprocal trust we have with them. When we encounter others, we encounter them as embodied beings, not simply as minds animating bodies. ${ }^{145}$

By contrast, when we consider autonomy, we tend to focus on the cognitive and volitional aspects of agency, which conceptually can be divorced from embodiment. The Platonic image of the unruly parts of the soul encourages us to think in terms of the intellectual ability to control the passions and, in important respects, deny our bodily existence. ${ }^{146}$ Protecting self expression through the First Amendment is a way of protecting the intellectual ways in which we understand ourselves and others. Organizations may not have bodies, but they have identities and are also capable of constitutionally protected expression. When we consider the autonomy of expression, or the autonomy of choices about how to live life, we focus on cognitive and volitional aspects of our lives. Although these aspects are no doubt constitutive, they are not exhaustive of our experience.

Human life and action are also unavoidably embodied. Philosophers as well as social psychologists emphasize the fact that embodied aspects of our

142. Id. at 567 .

143. See, e.g., ERWIN STRAuS, The Upright Posture, in PHENOMENOLOGICAl PSYCHOLOGY: THE SELECTED PAPERS OF ERWIN W. STRAUS 139 (Erling Eng trans., 1966) ("Upright posture preestablishes a definite attitude toward the world; it is a specific mode of being-in-the-word.").

144. Id.; see also Erving Goffman, The Interaction Order, 48 AM. SOCIOLOGICAL REV. 1, 4 (1983) ("By definition, we can participate in social situations only if we bring our bodies and their accoutrements along with us, and this equipment is vulnerable by virtue of the instrumentalities that others bring along with their bodies.").

145. See M. Merleau-Ponty, Phenomenology OF Perception 346-65 (Colin Smith trans., 1962).

146. Plato, PHAEdRus (Alexander Nehamas \& Paul Woodruff trans.), in PLATO: COMPLETE WORKS (John M. Cooper ed., 1997). 
lives can be inseparable from who we are and how we experience the world. ${ }^{147}$ So when the State seeks to control aspects of our embodied lives, the State may intrude into those aspects of our lives from which our experience of ourselves is inseparable. The experience of sex and sexuality are intrinsically bodily, and often shared with others. Just as our identities are inseparable from our embodied experiences, personal relationships are inseparable from embodied relations to others. We share physical and public space with others, altering our behavior by their mere presence, even in "the most private human conduct, sexual behavior, and in the most private of places, the home."148 How we act in the presence of others, what we reveal about ourselves to others, partially constitute the boundaries between privacy and publicity. As the philosopher Charles Taylor explains, "[m]y sense of myself, of the footing I am on with others, is in large part also embodied. The deference I owe you is carried in the distance I stand from you, in the way I fall silent when you start to speak, in the way I hold myself in your presence."149

Arguing that much of what is important in our moral lives is intertwined with our affirmation of ordinary life, Taylor writes:

[O]ur dignity is so much woven into our very comportment. The very way we walk, move, gesture, speak is shaped from the earliest moments by our awareness that we appear before others, that we stand in public space, and that this space is potentially one of respect or contempt, of pride or shame. Our style of movement expresses how we see ourselves as enjoying respect or lacking it, as commanding it or failing to do so. ${ }^{150}$

Our dignity is not only woven into our embodied relations with others in private, but is essential to how we relate to others in public. We are in the presence of other persons in myriad spaces, some of which afford greater intimacy and seclusion, others of which occur in undifferentiated public places.

In both private and public settings we are exposed to others, and thereby made vulnerable to them both physically and attitudinally, as Jean-Paul Sartre suggests. ${ }^{151}$ Sartre writes, when one becomes "conscious of being looked at," one realizes "that I am vulnerable, that I have a body which can be hurt, that I

147. See, e.g., ERVING GofFMAN, THe Presentation OF Self IN EVERyday life (1973); MARK JOHNSON, THE BODY IN THE MIND: THE BODILY BASIS OF MEANING, IMAGINATION, AND REASON (1987); MARTha C. NuSSBaum, Hiding From Humanity: Disgust, SHAME, AND THE LAW (2004).

148. Lawrence v. Texas, 539 U.S. 558, 567 (2003).

149. CHARLES TAYLOR, PHILOSOPHICAL ARGUMENTS 171 (1995).

150. TAYLOR, supra note 79 , at 15 .

151. Jean-Paul Sartre argues that one's whole orientation to the world changes when one becomes the object of another's look: "If someone looks at me, I am conscious of being an object." JEAN-PAUL SARTRE, BEING AND NOTHINGNESS 363 (Hazel E. Barnes trans., 1956). 
occupy a place and that I can not in any case escape from the space in which I am without defense-in short, that I am seen."152 Vulnerability can lead to harm in myriad ways. For example, open hostility, as well as exposure to acts constituting assault or battery, are ways we are physically vulnerable to others. Moreover others may fail to offer us the respect or recognition we are owed as persons, even in the simplest courtesies of everyday life. ${ }^{153}$ Our embodied lives can be disrupted by the State crossing the boundaries of our shared, yet private, lives. ${ }^{154}$ The State can physically restrain, socially demean, and politically monitor our shared lives. Vulnerability to state surveillance, such as being seen in a protected sphere of privacy like the home, also implicates core Fourth Amendment concerns. ${ }^{155}$

When the Laurence Court suggests that "[t]he State cannot demean [homosexuals'] existence or control their destiny" ${ }^{\text {"156 }}$ through criminal statutes, it confirms the centrality of interpersonal relations to human dignity. ${ }^{157}$ How a person's embodied existence can be defined as homosexual depends on the nature of that person's relationship to others. ${ }^{158}$ That relationship, and the bodily contact it involves, is what the State may not control without violating the dignity of persons. The Laurence Court also confirms that we remain vulnerable

152. Id. at 347 .

153. See AXel HONNETH, The Struggle For ReCOGNition: THe Moral Grammar of SOCIAL CONFlCTS 92 (Joel Anderson trans., Polity Press 1995) ("[T]he reproduction of social life is governed by the imperative of mutual recognition, because one can develop a practical relation-toself only when one has learned to view oneself, from the normative perspective of one's partners in interaction, as their social addressee.").

154. The State can dominate shared spaces, the public sphere, in greater or lesser ways. See ERVING GOFFMAN, ASYLUMS 23-32 (1961). Invading spaces in which we engage in our most embodied activities is central to our understanding of privacy. "Certainly in common usage a basic meaning of privacy is that of a private space, like a bathroom or a home, from which others may be excluded." Post, supra note 139 , at 971 .

155. See generally Kyllo v. United States, 533 U.S. 27 (2001).

156. Lawrence v. Texas, 539 U.S. 558, 578 (2003).

157. Laurence Tribe argues:

The 'liberty' of which the Court spoke was as much about equal dignity and respect as it was about freedom of action-more so, in fact. And the Court left no doubt that it was protecting the equal liberty and dignity not of atomistic individuals tom from their social contexts, but of people as they relate to, and interact with, one another.

Tribe, supra note 34, at 1898 .

158. The social act of defining sexuality is one fraught with difficulty, as many others have argued. See MICHEL FOUCAULT, THE HISTORY OF SEXUALITY, VOL. 1: AN INTRODUCTION (Robert Hurley trans., 1978). Legal rules treating sexuality are also sometimes vexed. See Zachary Kramer, Heterosexuality and Title VII, 103 Nw. U. L. REV. 205 (2009) (arguing that courts have read Title VII from a heteronormative perspective). 
to the possibility that others will not respect our forms of everyday life or our dignity as free persons. ${ }^{159}$

We manifest our human dignity through the relationships we form and the commitments we keep. The Laurence majority recognized that "dignity as free persons" requires protection for adults who choose to enter into intimate relationships with others. ${ }^{160}$ In order to respect the dignity of persons, the State must not intrude into the self-determining and life-constituting relations that are necessary for living in the company of others. Not only does fulfillment of the liberty of persons require interpersonal relations, it also requires shared spaces of interpersonal and embodied interaction wherein these relationships may exist.

As the constitutional history of the concept reveals, and the political hostility to its protection may caution, privacy, as a specific articulation of one aspect of liberty, is fraught with difficulty. James Whitman has gone so far as to claim that "[t]here is no such thing as privacy as such." ${ }^{161}$ We protect something we call privacy in multiple contexts where it plays multiple roles in our lives. Privacy's fecundity lies in its ability to organize diffuse rights protections, from the First Amendment's protection of the possession of obscene material in the home in Stanley $\nu$. Georgia, ${ }^{162}$ to its protection of choices involving childbirth in Roe $v$. Wade, ${ }^{163}$ to its protection of telephone booth conversations in Katz $v$. United States, ${ }^{164}$ all of which protect forms of everyday private life. Privacy's barrenness, by contrast, lies in its lack of specific textual grounding and indeterminate meaning. It is almost as if a right that is everywhere visible is nowhere to be found, a chimera always gesturing towards something else fundamental at stake. These various privacy protections, as Laurence teaches, are all ways of protecting the liberty to share forms of life in interpersonal relationships with others. As the Court in Planned Parenthood

159. Dignity has not played as prominent a role in American constitutional thinking. It is a comerstone, however, of international human rights. Article 1 of the Universal Declaration of Human Rights, for example, provides: "All human beings are born free and equal in dignity and rights. They are endowed with reason and conscience and should act towards one another in a spirit of brotherhood." Universal Declaration of Human Rights, G.A. Res. 217A (III), art. 1, U.N. GAOR, 3d Sess., U.N. Doc. A/810 (Dec. 12, 1948); see also Christopher McCrudden, Human Dignity and Judicial Interpretation of Human Rights, 19 EUR. J. INT'L. L. 655, 679-80 (2008) (developing conception of a minimum content for "human dignity"); Whitman, supra note 111.

160. Laurence, 539 U.S. at 567.

161. Whitman, supra note 111 , at 1221 .

162. Stanley v. Georgia, 394 U.S. 557, 564 (1969) ("For also fundamental is the right to be free, except in very limited circumstances, from unwanted governmental intrusions into one's privacy.").

163. 410 U.S. 113 (1973).

164. 389 U.S. 347 (1967). 
ข. Casey ${ }^{165}$ articulated the point in its closing sentences, by "interpreting the full meaning of the covenant in light of all of our precedents," the Court's task is to "define the freedom guaranteed by the Constitution's own promise, the promise of liberty." privacy as control over information or the home. This task recognizes the fullness of personal relations in shared private spaces, as well as associations in more public settings. The conceptual movement from privacy to liberty captures this more capacious understanding of "the Constitution's own promise."

As we shall see in the following section, privacy has settled more comfortably into Fourth Amendment jurisprudence where it can be controlled and circumscribed to mean secret, concealed, or hidden from view. By narrowly construing privacy as that which is kept secret from others, the Supreme Court's Fourth Amendment jurisprudence fails to acknowledge that interpersonal relationships play an important role in fulfilling the promise of liberty. In losing sight of liberty experienced through relations with others, and focusing on a narrow construction of privacy as secrecy, the Fourth Amendment now stands in considerable tension with actual social practices as well as the lessons of Laurence.

\section{INTERPERSONAL PRIVACY UNDER THE FOURTH AMENDMENT}

As a matter of everyday life, we are all vulnerable when speaking in confidence to other persons because they may repeat what we say. We all know the practical and theoretical nature of this structure well, at least as a feature of ordinary language. Once we utter an expression or communicate a message, we can no longer lay claim (if ever we could) to control the meaning of what we say or to limit its iteration beyond this context, in our presence, with regard to this text. ${ }^{168}$ To use the language of legal discourse central to Fourth Amendment analysis, we "assume the risk" that other persons will do with our words what they will. Meaning is slippery, and there are no guarantees that the messages we send will be received with the content we intended. For example, we assume a risk of infelicity, of misfire, a risk that the listener or reader will fail to understand what we intend to convey, that our messages

165.

505 U.S. 833 (1992).

166. Id. at 901 .

167. Id.

168. See JACQUES DERRIDA, LIMITED INC (1988). Of course, I don't mean to suggest that clarifications and further reiterations are not possible, see, e.g., H.P. Grice, Meaning, 66 PHIL. REV. 377 (1957), but simply that in circulating meanings tied to practices that exceed anything private and particular to me, I must always express myself through publicly available modes of expression that exceed my control. See, e.g., J.L. AUSTIN, How TO DO THINGS WITH WORDS (1962); STANLEY CAVELL, MUST WE MEAN WHAT We SAY? 42 (1976). 
will not be received. ${ }^{169}$ We also assume the risk that what we say will be repeated out of context, construed and repeated to mean something we did not say or intend to say. These are the risks associated with ordinary language use, with the writing and saying that comprise much of our shared social lives. But this is not the assumed risk that touches fundamental aspects of constitutional law and principle.

More than infelicity, in choosing to speak, we assume the risk of a particular form of repetition. Whenever we communicate with others through speech or writing, they may repeat our words, thoughts, and meanings in contexts and to others in ways we may neither intend nor desire. More particularly, we assume the risk that in sharing, other persons will take our words to have legal significance-as evidence of criminal wrongdoing or political dangerousness-and repeat them to an officer of the State. Whether in the presence of informants, ${ }^{170}$ eavesdropping devices, ${ }^{171}$ or the consent of another, ${ }^{172}$ we assume the risk that when speaking to another person, we are talking to a state agent. When speaking to other persons, we lose control of our words and unveil the privacy of our thoughts, which may then be conveyed to the State irrespective of any desire we may have to limit our speech to the present company or a chosen audience.

Such a situation is not only acceptable under current constitutional doctrine, but perhaps socially desirable. For example, community policing thrives on citizens cooperatively reporting illegal activity to authorities. ${ }^{173}$ Effective crime prevention and investigation often require citizens to convey to government agents what they know about other persons' statements, attitudes, and behaviors. To be part of a community is to be open in some respects to surveillance by one's neighbors, who act as the first line of police, ensuring that individual behavior conforms to community standards. Community policing has costs and benefits, but one assumption of the practice is that persons have no right of privacy in their publicly observable behavior or in

169.

See AUsTIN, supra note 168 , at 14 .

170. Hoffa v. United States, 385 U.S. 293 (1966).

171. United States v. White, 401 U.S. 745, 751 (1971).

172. See Smith v. Maryland, 442 U.S. 735, 741-42 (1979) (conveying telephone pen register information to police); United States v. Miller, 425 U.S. 435, 443 (1976) ("[T]he Fourth Amendment does not prohibit the obtaining of information revealed to a third party and conveyed by him to Government authorities.").

173. See Tracey L. Meares \& Dan M. Kahan, The Wages of Antiquated Procedural Thinking: A Critique of Chicago v. Morales, 1998 U. CHI. LEGAL F. 197, 211; Debra Livingston, Police Discretion and the Quality of Life in Public Places: Courts, Communities and the New Policing, 97 CoLUM. L. REV. $551,575-78(1997)$. 
their communications with others. ${ }^{174}$ In the following section, this Article examines the Fourth Amendment framework within which we assume the risk of state intrusion into our interpersonal lives through our everyday acts of sharing.

\section{A. Assuming the Risk of Disclosure}

We share information about ourselves to many others in multiple settings. Even when we share with others in particular relationships for specific purposes, we often expect privacy. Focused on privacy as nondisclosure, however, the Supreme Court has repeatedly held that we have no Fourth Amendment expectation of privacy in what we voluntarily disclose to others. Consent operates in two ways to compromise privacy: we voluntarily convey information to third parties, and third parties voluntarily repeat information to state officials. An examination of the cases reveals that the former may often be illusory, and the latter may sometimes be spurious. As this section illustrates, if privacy protects only what we keep to ourselves, the Fourth Amendment fails to apply to many practices ordinarily thought to be private.

In a series of cases, the Supreme Court has made clear that persons have no expectation of privacy in what they knowingly expose to the public. ${ }^{175}$ As the foundational modern case, Katz $v$. United States, ${ }^{176}$ explained: "What a person knowingly exposes to the public, even in his own home or office, is not a subject of Fourth Amendment protection. But what he seeks to preserve as private, even in an area accessible to the public, may be constitutionally protected." 177 The Katz framework defines a search primarily by objectively reasonable social expectations of privacy: if there is no expectation of privacy, then there is no search for constitutional purposes. ${ }^{178}$ Much therefore depends on how the Supreme Court assesses expectations of privacy.

174. See, e.g., United States v. Lee, 274 U.S. 559, 563 (1927) (relying on public exposure of cans of alcohol on deck of a boat); see also Aya Gruber, Garbage Pails and Puppy Dog Tails: Is That What Katz Is Made Of?, 41 U.C. DAVIS L. REV. 781, 799 (2008) (arguing that instead of discussing privacy in terms of society's actual beliefs about what is shielded from public viewing, the Supreme Court has "basically held that the remote possibility of disclosure renders unreasonable an individual's privacy expectations"); Bridget Mallon, Comment, "Every Breath You Take, Every Move You Make, I'll Be Watching You": The Use of Face Recognition Technology, 48 VILL. L. REV. 955, 977 (2003) (opining that facial recognition technology does not constitute an invasion of privacy because "[m]ost Americans are not, and may never be, ready to accept that an individual can expect to maintain his or her privacy when he or she is in public").

175. See, e.g., United States v. Miller, 425 U.S. 435, 442-43 (1976); Katz v. United States, 389 U.S. 347, 351-52 (1967).

176. 389 U.S. 347.

177. Id. at 351-52.

178. Justice Harlan, writing in concurrence, stated the rule the Court has followed as "a twofold requirement, first that a person have exhibited an actual (subjective) expectation of privacy and, 
A jurisprudence of public visibility is central to Fourth Amendment analysis. State officers are permitted to see whatever one exposes to the public, whether in one's trash, ${ }^{179}$ on one's property, ${ }^{180}$ or on the road. ${ }^{181}$ The consequences of public visibility can be avoided only by hiding from view those items one wishes to keep private. Even within the confines of one's own backyard, yet outside the protective curtilage of the home, one's activities are vulnerable to observation by agents of the State, whether from the air ${ }^{182}$ or from a vantage on the property. ${ }^{183}$ Moreover, when officers are where they are legally entitled to be, ${ }^{184}$ and look where they are entitled to look, ${ }^{185}$ whatever they see receives no Fourth Amendment protection. Police officers are not required to shield their eyes from what is readily apparent in order to protect privacy. ${ }^{186}$ This logic also applies to the supposed sui generis nature of the dog's nose, capable of smelling the public odor of illegal narcotics in a suitcase

second, that the expectation be one that society is prepared to recognize as 'reasonable." Id. at 361 (Harlan, J., concurring).

179. See California v. Greenwood, 486 U.S. 35, 44-45 (1988).

180. "Olpen fields do not provide the setting for those intimate activities that the Amendment is intended to shelter from government interference or surveillance. There is no societal interest in protecting the privacy of those activities, such as the cultivation of crops, that occur in open fields." Oliver v. United States, 466 U.S. 170, 179 (1984). Similar reasoning applies to state officers occupying fixed wing aircraft, see California v. Ciraolo, 476 U.S. 207 (1986), and helicopters, see Florida v. Riley, 488 U.S. 445 (1989), in order to view property from the airspace above. One knowingly exposes one's backyard activities to aerially positioned state officers. Outside the curtilage of the home, government agents' ability to conduct aerial surveillance is not limited by the Fourth Amendment. See Dow Chem. Co. v. United States, 476 U.S. 227, 237 (1986) ("[W]e find it important that this is not an area immediately adjacent to a private home, where privacy expectations are most heightened,").

181. United States v. Knotts, 460 U.S. 276, 281-82 (1983) (noting that when the defendant "traveled over the public streets he voluntarily conveyed to anyone who wanted to look the fact that he was traveling over particular roads in a particular direction, the fact of whatever stops he made, and the fact of his final destination when he exited from public roads onto private property").

182. See Riley, 488 U.S. at 445.

183. See United States v. Dunn, 480 U.S. 294, 304-05 (1987) (concluding that peering into a barn outside the curtilage of the house in open fields does not constitute a search).

184. See Horton v. California, 496 U.S. 128, 136 (1990) ("It is, of course, an essential predicate to any valid warrantless seizure of incriminating evidence that the officer did not violate the Fourth Amendment in arriving at the place from which the evidence could be plainly viewed."); Arizona v. Hicks, 480 U.S. 321 (1987) (articulating the "plain view" standard).

185. Much Fourth Amendment doctrine derives from considering whether a police officer had the requisite justification for looking at particular items, such as the contents of a crumpled cigarette pack, see United States v. Robinson, 414 U.S. 218, 236 (1973), or inside a paper bag on a car floorboard, see Florida v. Jimeno, 500 U.S. 248 (1991). Even when officers illegally trespass on private property, their actions do not necessarily violate a constitutionally recognized expectation of privacy. See Oliver, 466 U.S. at 178 ("[A]n individual may not legitimately demand privacy for activities conducted out of doors in fields, except in the area immediately surrounding the home" even when police trespass on the fields).

186. See, e.g., California v. Ciraolo, 476 U.S. 207, 213-14 (1986) ("Any member of the public flying in this airspace who glanced down could have seen everything that these officers observed."). 
or car. ${ }^{187}$ Even though narcotics officers can learn some information about the contents of luggage, the Court reasoned in United States $\nu$. Place ${ }^{188}$ that "the sniff discloses only the presence or absence of narcotics." 89 Thus, what is apparent to the eyes, or to a dog's nose, receives no constitutional protection. ${ }^{190}$

A jurisprudence of hearing mimics that of seeing. Government agents are free to pose as ordinary citizens, gain the confidence of unwitting persons, and testify in court about what they saw and heard. ${ }^{191}$ Moreover, the government is free to benefit from ordinary citizens operating as informants. ${ }^{192}$ If an agent or informer wears a recording device, officials may also receive the benefits of technology, free from Fourth Amendment limitation. ${ }^{193}$ Why do persons receive no search or seizure protections in these circumstances? The Court in Hoffa v. United States ${ }^{194}$ recited the assumption-of-risk rationale to answer this question: "The risk of being overheard by an eavesdropper or betrayed by an informer or deceived as to the identity of one with whom one deals is probably inherent in the conditions of human society. It is the kind of risk we necessarily assume whenever we speak." ${ }^{\prime 195}$

Under Katz, one assumes the risk of knowingly exposing conversations or actions to the public when the public consists of invited visitors to one's hotel suite, ${ }^{196}$ or even when the public is a single person in one's own home. ${ }^{197}$ In essence, a person broadcasts to the world what he tells to a close confidant under the "risk that his companions may be reporting to the police."198 The nature of the place where the conversation occurs does not matter, for even in the security of one's own home, when one shares a conversation, one is knowingly exposing one's thoughts and intentions to the public. Police officers are not required to cover their ears.

Under this assumption-of-risk analysis, "privacy" is understood to have a very narrow scope, while "public" is understood broadly. An everyday concep-

187. See Illinois v. Caballes, 543 U.S. 405 (2005); Unired States v. Place, 462 U.S. 696, 707 (1983) (reasoning that "the canine sniff is sui generis").

188. 462 U.S. 696 (1983).

189. Id. at 707 .

190. See Albert W. Alschuler, Interpersonal Privacy and the Fourth Amendment, 4 N. ILL. U. L. REV. 1, 32 n.94 (1983) ("[T]he fourth amendment creates no right to share information with all the world save governmental officers.").

191. Lewis v. United States, 385 U.S. 206 (1966).

192. Hoffa v. United States, 385 U.S. 293 (1966).

193. United States v. White, 401 U.S. 745 (1971); see also Lopez v. United States, 373 U.S. 427 (1963); On Lee v. United States, 343 U.S. 747 (1952).

194. 385 U.S. 293.

195. Id. at 303 .

196. Id. at 300-03.

197. Lewis v. United States, 385 U.S. 206, 210-11 (1966).

198. White, 401 U.S. at 752. 
tion of privacy as including one's communications with other people animates Justice Douglas's impassioned dissent in United States v. White. ${ }^{199}$ He recognizes that "[t]he individual must keep some facts concerning his thoughts within a small zone of people," yet "[m]onitoring, if prevalent, certainly kills free discourse and spontaneous utterances." 200 Yet the Court employs the assumption-of-risk rationale to construe the public as a single individual, so that if one shares thoughts or intentions with anyone, the other person becomes one's "public" for Fourth Amendment purposes. ${ }^{201}$ As the Supreme Court has explained:

It is well settled that when an individual reveals private information to another, he assumes the risk that his confidant will reveal that information to the authorities, and if that occurs the Fourth Amendment does not prohibit governmental use of that information. Once frustration of the original expectation of privacy occurs, the Fourth Amendment does not prohibit governmental use of the now non-private information. ${ }^{202}$

Because shared information spreads through repetition at the discretion of others, acts of sharing always risk exposure to state officials under the current law of search and seizure.

Individuals are always free to cooperate with police, by consenting to searches and seizures that officers could not independently justify. Fourth Amendment jurisprudence limits what state officers may do only in the absence of consent. If persons voluntarily repeat to state agents what they have heard, or consent to show state agents private spaces, the Court has made clear that there is no Fourth Amendment protection afforded to that which is revealed. ${ }^{203}$ As a rule, a person consents to a search when she would have felt free to decline the officer's request to search. ${ }^{204}$ As a matter of practice, police have a strong incentive to obtain consent, and thereby operate free from constraining Fourth Amendment rules.

In order to determine whether consent was given in particular situations, the Court has refused to look at the circumstances or social structures that

199. 401 U.S. 745.

200. Id. at 762-63 (Douglas, J., dissenting).

201. See William C. Heffernan, Fourth Amendment Privacy Interests, 92 J. CRIM. L. \& CRIMINOLOGY 1, 38 (2001) (noting that under the Court's privacy expectation, "even the slightest exposure of an item to the public can defeat a privacy claim").

202. United States v. Jacobsen, 466 U.S. 109, 117 (1984) (holding that there is no privacy in a shared footlocker).

203. See Florida v. Jimeno, 500 U.S. 248, 252 (1991) ("A suspect may of course delimit as he chooses the scope of the search to which he consents. But if his consent would reasonably be understood to extend to a particular container, the Fourth Amendment provides no grounds for requiring a more explicit authorization."); Schneckloth v. Bustamonte, 412 U.S. 218 (1973).

204. Florida v. Bostick, 501 U.S. 429, 434 (1991). 
might impact whether consent is voluntary. ${ }^{205}$ For example, race may sometimes play a significant role. Tracey Maclin argues that "for most black men, the typical police confrontation is not a consensual encounter." 206 Moreover, background social practices and expectations based on perceived social roles place intense social and psychological pressure on individuals to comply with police officer requests. ${ }^{207}$ For example, we are often taught as children to cooperate with police officers, and are encouraged to defer to requests by those perceived to have authority. This pressure, together with a widespread belief that we have no genuine choice and must consent to requested searches, partially explains why so many individuals carrying illegal narcotics nonetheless consent to searches. Moreover, by targeting the poor, minorities, and those who live in more visible places, or drive vehicles more susceptible to technical violations, there is an uneven distribution of whose consent is regularly sought. ${ }^{208}$ Despite the racial, social, and psychological problems with consent between citizens and police, consent remains a vital part of police practice, ${ }^{209}$

205. See, e.g., United States v. Cruz-Mendez, 467 F.3d 1260, 1265-66 (10th Cir. 2006) (rejecting claim that consent was necessarily coerced when multiple officers were present, asked about immigration status, and said they would get a search warrant); United States v. Snype, 441 F.3d 119 (2d Cir. 2006) (affirming valid consent after SWAT team forcibly entered residence, raised possibility of taking child, and then asked for permission to search home); United States v. Smith, 973 F.2d 1374 (8th Cir. 1992) (finding valid consent when officers met wife at door with weapons drawn, asked if husband was inside, and "asked" to come inside); United States v. Gilbert, 829 F. Supp. 900 (E.D. Mich. 1993) (affirming valid consent when agents arrested defendant in bedroom, handcuffed him, took him to another room, and then asked permission to search home).

206. Tracey Maclin, "Black and Blue Encounters"-Some Preliminary Thoughts About Fourth Amendment Seizures: Should Race Matter?, 26 VAL. U. L. REV. 243, 272 (1991); see also DAVID COLE, NO EQUAL JUSTICE 31 (1999) ("Because a consent search requires no objective individualized suspicion, it is more likely to be directed at poor young black men than wealthy white elderly women."); Tracey Maclin, The Decline of the Right of Locomotion: The Fourth Amendment on the Streets, 75 CORNELL L. REV. 1258, 1306 (1990) ("[V] ery few persons will have the moxie to assert their fourth amendment rights in the face of police authority."). Two key Supreme Court cases featuring contested consent searches include: United States v. Drayton, 536 U.S. 194 (2002) (holding that officers do not have an obligation to inform citizens that they do not have to consent to a requested search of their possessions), and Bostick, 501 U.S. at 436 (holding that voluntary consent is determined by "whether a reasonable person would feel free to decline the officers' requests or otherwise terminate the encounter"). See also California v. Hodari D., 499 U.S. 621, 628 (1991) (holding a seizure does not occur where a reasonable person would feel free "to disregard the police and go about his business").

207. Janice Nadler, No Need wo Shout: Bus Sweeps and the Psychology of Coercion, 2002 SUP. CT. REV. 153, 205 (discussing psychological studies that find that "people who are targeted for a search by police and informed that they have a right to refuse nonetheless feel intense pressure to comply and feel that refusal is not a genuine option").

208. See William J. Stuntz, The Distribution of Fourth Amendment Privacy, 67 GEO. WASH. L. REV. 1265, 1266 (1999) ("Privacy, in Fourth Amendment terms, is something that exists only in certain types of spaces; not surprisingly, the law protects it only where it exists. Rich people have more access to those spaces than poor people; they therefore enjoy more legal protection.").

209. See Ohio v. Robinette, 519 U.S. 33, 40 (1996) (describing how officer who gained consent in contested search requested consent to search vehicles in 786 traffic stops in one year alone). 
and a central mechanism by which persons are rendered vulnerable through their acts of sharing. We may have some control over whether we consent to a search, but we have even less control over whether those with whom we share our lives might consent to a search of shared possessions or places in our absence. ${ }^{210}$

Incident to many transactions in modern life, we reveal copious amounts of information to third parties, be they merchants, banks, airlines, telephone providers, utility companies, or others. Even when it is difficult to claim that we have voluntarily consented to reveal private information, the fact that we have shared the information means that we have relinquished an expectation that it "will remain secret," When the Court construes privacy narrowly as secrecy, as it often does, then once a person reveals information to a third party, government agents are free to benefit from that act of sharing. ${ }^{213}$ When we make phone calls, we "voluntarily convey[ ] numerical information to the telephone company and 'expose[]' that information," which in turn means that we "assume[ ] the risk that the company would reveal to police the numbers" we dialed. ${ }^{214}$ As Justice Marshall noted in his Smith dissent, it is difficult to understand in what sense we "voluntarily" convey information to the telephone company when such conveyance is a necessary condition for use of the telephone. ${ }^{215}$ Presumably, we have a choice not to use the telephone if we wish to keep the numbers we would have dialed private. A similar situation exists for bank records or loan applications. If we wish to participate in the modern economy, we must have a bank account. But in so doing, we "voluntarily" convey to our bank private information about our transactions about which we no longer have an expectation of privacy: "The depositor takes the risk, in revealing his affairs

210. There are limits, however, as to who is understood to have sufficient authority to consent to a search. A hotel clerk, for example, does not have authority to consent to a search of a guest's hotel room. See Stoner v. California, 376 U.S. 483, 488 (1964); United States v. Jeffers 342 U.S. 48 (1951). Nor does a landlord have authority to consent to a search of a tenant's home. See Chapman v. United States, 365 U.S. 610, 616-18 (1961).

211. Smith v. Maryland, 442 U.S. 735, 743 (1979).

212. Id.

213. "The cases and literature on search and seizure, and to a lesser extent on self-incrimination, routinely emphasize the individual's ability to keep some portion of his life secret, at least from the government." William J. Stuntz, Privacy's Problem and the Law of Criminal Procedure, $93 \mathrm{MICH}$. L. REV. 1016, 1016 (1995).

214. Smith, 442 U.S. at 744.

215. "[U]nless a person is prepared to forgo use of what for many has become a personal or professional necessity, he cannot help but accept the risk of surveillance. It is idle to speak of 'assuming' risks in contexts where, as a practical matter, individuals have no realistic alternative." Id. at 750 (Marshall, J., dissenting) (citation omitted). One could add: "To read the Constitution more narrowly is to ignore the vital role that the public telephone has come to play in private communication." Katz v. United States, 389 U.S. 347, 352 (1967). 
to another, that the information will be conveyed by that person to the Government."216 There are large parts of our lives in which we reveal limited information about ourselves to others for specific, transactional purposes, with the expectation that the use of such information will be circumscribed by the limited transactional purpose. ${ }^{217}$ If government officials were to compile this information, as they may without judicial supervision under current case law, they could learn much about our private lives.

Ordinarily, we consent to convey information necessary to complete each transaction whenever we could choose not to engage in the transaction. Of course, such a choice is often illusory. Thus, although consent is a significant analytic element in determining what is public, consent need only be nominal to trigger assumed risks of exposure of otherwise private information to government officials.

\section{B. Assuming the Risk of a Shared Life}

Consent creates assumed risks not only regarding shared information, but also shared spaces and possessions. When we share our lives with others, under the Supreme Court's third-party consent doctrine we assume the risk that they will consent to police searches over the places and items that we share. ${ }^{218}$ For example, in Frazier ข. Cupp, ${ }^{219}$ the Court considered a motion to suppress evidence obtained from the search of a duffel bag. ${ }^{220}$ The defendant left the bag temporarily with his cousin, who, when confronted by inquiring officers, granted consent to search the bag. The Court in a later case described the situation as one in which "the defendant had assumed the risk that his cousin, with whom he shared the bag, would allow the police to search it."221 Ordinary acts of sharing with those who are close to us, whether as associates, friends, or relatives, render us vulnerable to how well they can withstand any police pressure urging consent to search our belongings. Sharing with others is risky.

Assumed risk is also endemic to the space which by tradition has been afforded the greatest Fourth Amendment protection against government

216. United States v. Miller, 425 U.S. 435, 443 (1976) (applying assumption of risk for information found on loan applications); see also United States v. Payner, 447 U.S. 727 (1980).

217. See SlOBOGIN, supra note 4; Daniel J. Solove, Access and Aggregation: Public Records, Privacy and the Constitution, 86 MINN. L. REV. 1137, 1177-79, 1185 (2002).

218. Consent plays a central role in mediating the State's involvement in undercover informant, third party or false friend cases. See Kerr, supra note 4.

219. 394 U.S. 731 (1969).

220. Id. at 740 .

221. Schneckloth v. Bustamonte, 412 U.S. 218, 245 (1973). 
intrusion-the home. ${ }^{222}$ To emphasize the constitutional importance of the home as a place wherein paradigmatic privacy protections reside, the Court has stressed the fact that "[t]he Fourth Amendment protects the individual's privacy in a variety of settings. In none is the zone of privacy more clearly defined than when bounded by the unambiguous physical dimensions of an individual's home."223 Common law tradition from English cases such as Wilkes ข. Wood ${ }^{224}$ and Fourth Amendment jurisprudence consistently "draws . . . a firm but also bright ${ }^{\prime 225}$ line at the entrance to the house as a particularly important domain of personal and familial privacy. Still, if one shares a house with another, "that other can grant access to the police in each instance." ${ }^{1226}$ Despite its protected status, the home is also a place fraught with risk, at least for anyone who shares her home with others. The facts in United States v. Matlock ${ }^{227}$ illustrate the risk.

William Earl Matlock was arrested in the front yard of his home, detained in a squad car parked nearby, and asked no questions of consent to search his home. ${ }^{228}$ Instead, three officers went to the front door of the residence where they encountered twenty-one year old Gayle Graff dressed in a robe and holding her three year old son. Mr. Matlock shared the house with Mr. and Mrs. Marshall and their daughter Gayle. Although the issue was disputed, the Court accepted the finding that Ms. Graff had consented to the warrantless search of the home, where the police found evidence of Mr. Matlock's criminal wrongdoing. ${ }^{229}$ It is important to note that Mr. Matlock was not asked for his consent; rather, consent was sought and obtained from a person with whom Mr. Matlock shared a dwelling. Consent from another sufficed because state officials need only "show that permission to search was obtained from a third party who possessed common authority over or other sufficient relationship to

222. See, e.g., Wilson v. Layne, 526 U.S. 603, 610 (1999) (referring to the "centuries-old principle of respect for the privacy of the home"); Payton v. New York, 445 U.S. 573, 601 (1980) (stressing "the overriding respect for the sanctity of the home that has been embedded in our traditions since the origins of the Republic").

223. Payton, 445 U.S. at 589; see also United States v. Karo, 468 U.S. 705, 714 (1984) ("[T]he individual normally expects privacy free of governmental intrusion not authorized by a warrant, and that expectation is plainly one that society is prepared to recognize as justifiable.").

224. (1763) 98 Eng. Rep. 489 (C.P.) (noting successful suit for trespass for King's officers' search of home for personal books and papers); Entick v. Carrington, (1765) 95 Eng. Rep. 807 (K.B.) (same); see also Boyd v. United States, 116 U.S. 616, 630 (1886) ("It is not the breaking of his doors, and the rummaging of his drawers, that constitutes the essence of the offence; but it is the invasion of his indefeasible right of personal security, personal liberty and private property....").

225. Kyllo v. United States, 533 U.S. 27, 40 (2001).

226. Georgia v. Randolph, 547 U.S. 103, 134 (2006) (Roberts, C.J., dissenting).

227. 415 U.S. 164 (1974).

228. Id. at $166,179$.

229. Id. 
the premises or effects sought to be inspected." ${ }^{230}$ As shall become apparent shortly, the language of "other sufficient relationship" allows great latitude for police consent. This latitude exists not only in cases where one leaves a duffel bag with a cousin, as in Frazier $v$. Cupp, ${ }^{231}$ on which the Matlock Court relied, but in other occasions of real or perceived authority over shared spaces and items. ${ }^{232}$ In a footnote, the Matlock Court further explained that thirdparty consent does not rest on property interests, but on "mutual use" such that "the others have assumed the risk that one of their number might permit the common area to be searched." ${ }^{233}$ Thus, the police are free to use a show of official authority (three officers at the door), under conditions most favorable to them (the target of the search ensconced in the squad car), to persuade third parties to grant consent for household searches. ${ }^{234}$

In Matlock the Court made clear that "the consent of one who possesses common authority over premises or effects is valid as against the absent, nonconsenting person with whom that authority is shared."235 What happens when the nonconsenting person is present to express an explicit withholding of consent? Do we "assume the risk that those who have access to and control over shared property might consent to a search" ${ }^{236}$ over our objections? In a narrow decision, the Court in Georgia v. Randolph ${ }^{237}$ held that "a warrantless search of a shared dwelling for evidence over the express refusal of consent by a physically present resident cannot be justified as reasonable as to him on the basis of consent given to the police by another resident." 238

Randolph required the Court to determine whose consent matters when co-occupants disagree over whether to permit police to search a shared space. In the context of a marital dispute, a wife informed the police of her husband's cocaine use, and consented to lead the officers to incriminating evidence

230. Id. at 171 .

231. 394 U.S. 731,740 (1969).

232. See, e.g., Moore v. Andreno, 505 F.3d 203 (2d Cir. 2007) (finding that society would not expect a girlfriend to have authority to consent to search of her boyfriend's study where she cut lock to gain access and told officers she was not allowed in the room); United States v. Rosario, 962 F.2d 733, 738 (7th Cir. 1992) (holding that though police knew person who answered door was not person who rented motel room, consent valid because person who answered door gestured for them to come in and acted as if he were "keeper of the door").

233. Matlock, 415 U.S. at $171 \mathrm{n} .7$.

234. By contrast, Justice Jackson cautioned, "The right of officers to thrust themselves into a home is also a grave concern, not only to the individual but to a society which chooses to dwell in reasonable security and freedom from surveillance." Johnson v. United States, 333 U.S. 10, 14 (1948).

235. Matlock, 415 U.S. at 170.

236. Georgia v. Randolph, 547 U.S. 103, 134 (2006) (Roberts, C.J., dissenting) (internal quotation marks omitted).

237. 547 U.S. 103.

238. Id. at 120 . 
located in the home. The husband, who was present at the threshold of the house, denied consent, and the question became whether the police could lawfully search pursuant to the consent of one occupant of a shared premises over the objection of another. A tenuous five-vote majority held that a warrantless search is not lawful in this narrow circumstance-when one occupant of a shared dwelling is physically present at the home's threshold to contest the consent offered by another resident. ${ }^{239}$ The fine line that the Court majority draws means that "the potential objector, nearby but not invited to take part in the threshold colloquy, loses out."240 When we are absent from our dwelling, even when we may be nearby, our choice to share our lives with others renders us vulnerable to the State. Just as we lose control of our words in our absence through the listener's power to repeat, so too we lose control of our space of privacy in our absence through the co-occupant's power to invite the State into a shared space.

Both Matlock and Randolph rely on what the Court construes as background social practice. ${ }^{241}$ Consent to allow others into the common dwelling is understood as customary social practice. If one shares a house with another person, that person, in one's absence, is certainly free to invite other persons into the home. Since anyone who lives with another person understands this social practice, the Court reasons that the police are entitled to rely on that practice when seeking consent to search a home. Recall that we have no expectation of privacy that the whole world except government agents may listen to what we say or learn from others what we have said. Likewise, we have no expectation of privacy that another household occupant can admit anyone in the world save government agents. ${ }^{242}$ Government agents act reasonably under the Fourth Amendment, according to this view, when they rely on ordinary social expectations and practices.

An established social practice is lacking in Randolph. The Court reasoned that there is no common social practice that would make it reasonable for a guest to feel welcome to enter a home when one of the residents objects to

239. Id. at 121 ("II]f a potential defendant with self-interest in objecting is in fact at the door and objects, the co-tenant's permission does not suffice for a reasonable search.").

240. Id.

241. Jonathan Simon argues that what is distinctive about Katz, and what Fourth Amendment jurisprudence since Katz has not fully appreciated, is "the degree to which 'the social' should enter into the consideration of the specific boundary of constitutional protections," in order "to imagine the social significance of the key aspects of a challenged police practice." Jonathan Simon, Katz at Forty: A Sociological Jurisprudence Whose Time Has Come, 41 U.C. DAVIS L. REV. 935, 944 (2008).

242. See Randolph, 547 U.S. at 109-10. 
her entry. ${ }^{243}$ This same background social practice, according to the Randolph majority, vitiates against allowing government agents permission to enter the home relying on one present consenting party over the refusal of another. ${ }^{24}$ Because of special constitutional solicitude for the privacy of the home, in the absence of a social practice that would indicate otherwise, the Court concluded that disputed permission to search the home does not outweigh the core Fourth Amendment value.

Treating privacy as a very narrow value defeasible by sharing information, belongings, or a home with even a single other person, Chief Justice Roberts dissented because the majority had not sufficiently appreciated the extent to which "a decision to share a private place, like a decision to share a secret or a confidential document, necessarily entails the risk that those with whom we share may in turn choose to share-for their own protection or for other reasons-with the police." ${ }^{245}$ While criticizing the majority's reliance on an empirically unsupported conception of social practice regarding disputed permission to enter a home, the dissent grounds its rationale on its narrow conception of privacy. In the dissent's view, sharing necessarily entails a loss of privacy, and thus an assumption of risk of exposure to government agents. This conception of privacy also relies on empirically unsupported generalizations about how privacy functions in social practice. Roberts writes that "by sharing private space, privacy has already been frustrated" with respect to the person with whom one has shared. ${ }^{246}$ Even if we have background social expectations that those with whom we share our lives will not cooperate with government agents, Roberts claims "[t]he Constitution, however, protects not these but privacy, and once privacy has been shared, the shared information, documents, or places remain private only at the discretion of the confidant." ${ }^{124}$

So far, we assume the risks of social life primarily because of the consent others might volunteer or the consent state agents might seek. Social life involves additional Fourth Amendment risks beyond those implicating consent. Even the presence of a houseguest can vitiate claims of privacy. One assumes

243. Id. at 113 ("Without some very good reason, no sensible person would go inside under those conditions.").

244. Id. at 114 ("[T]here is no common understanding that one co-tenant generally has a right or authority to prevail over the express wishes of another, whether the issue is the color of the curtains or invitations to outsiders.").

245. Id. at 142 (Roberts, C.J., dissenting).

246. Id. at 131 (internal quotation marks omitted).

247. Id. Sharing also produces risks when the relationship on which the sharing was based ends. See Illinois v. Rodriguez, 497 U.S. 177 (1990) (holding that a search reasonable where former a girlfriend retained a key to her boyfriend's apartment). Because Mr. Rodriguez was imperfect in his exercise of control over his private space-Ms. Fischer had a key, even if she did not have authority to admit guests-the State was allowed to exploit the vulnerability that arises from this imperfection. Id. 
the risk of sharing not only when one lives with another person, but also when one temporarily shares a dwelling with the other. In Minnesota $v$. Carter, ${ }^{248}$ the Supreme Court made clear that expectations of privacy were personal rights "that must be invoked by an individual," ${ }^{249}$ and that when visiting another person's place, one has no Fourth Amendment protected privacy interest. Whether a person receives Fourth Amendment protection depends on where she is and on the presence or absence of a "legitimate expectation of privacy in the invaded place."

In Carter, the place was a third person's ground floor apartment. The defendants were two men who spent two and a half hours as guests packaging cocaine. The police became aware of these activities by peering through gaps in the apartment's closed blinds, an activity that might reasonably be described as a search. Ordinarily, houses are places where people receive strong Fourth Amendment protection, but the Court reasoned that a person only sometimes receives that protection in the privacy of someone else's house. ${ }^{251}$ The defendants' claimed expectation of privacy flowed from their presence in a home with drawn blinds and from the social practice of persons sharing the privacy of their homes with others. In a prior case, Minnesota v. Olson, ${ }^{252}$ the Court had recognized a "longstanding social custom" and "the every-day expectations of privacy that we all share" when we are overnight guests at another's home. ${ }^{253}$ Yet, in another prior case, the Court rejected the narrow claim that "anyone legitimately on premises where a search occurs may challenge its legality."254 Nonetheless, the Olson Court spoke at some length about the background social practices that involve our sharing the privacy of our homes with others, even if the facts and holding of the case involved an overnight houseguest. ${ }^{25}$

Carter represented a further opportunity to clarify the extent to which ordinary social practices of living our lives in the company of others receive Fourth Amendment protection. While recognizing that the domestic place was significant, the Court concluded that the defendants had no expectation of privacy because of the temporary nature of the two-and-a-half-hour visit, the lack of prior connections to the householder, and the commercial nature

248. 525 U.S. 83 (1998).

249. Id. at 88 .

250. Id.

251. Id. at 89 .

252. 495 U.S. 91 (1990).

253. Id. at 98 .

254. Rakas v. Illinois, 439 U.S. 128, 135 (1978).

255. Olson, 495 U.S. at 99 ("The houseguest is there with the permission of his host, who is willing to share his house and his privacy with his guest."). 
of the activity of bagging cocaine. ${ }^{256}$ Oddly, there seemed to be no recognition that this reasoning applied all the more to Mr. Katz's occupancy of a glass phone booth- "a temporarily private place whose momentary occupants' expectations of freedom from intrusion are recognized as reasonable." ${ }^{257}$ It remains mysterious how the phone booth occupant has a reasonable expectation of privacy whereas the social guest of a private residence does not.

Thus, a person's temporary sharing of another's home makes her vulnerable to the State in a different way than when she shares her own residence or a conversation. When the State invades the homeowner's expectation of privacy, the guest has no constitutional objection grounded in "real or personal property law. "258 The temptation to engage in extralegal police practices is real, as Justice Ginsburg claimed in dissent: "Human frailty suggest that today's decision will tempt police to pry into private dwellings without warrant, to find evidence incriminating guests who do not rest there through the night."259 Justice Ginsburg highlights the "individual's choice to share her home and her associations there with persons she selects" as warranting protection under the Fourth Amendment. ${ }^{260}$ Under the assumption-of-risk rationale, our frustrated expectation of privacy is grounded in shared social practice and expectations about how we lead our lives in the company of others - social practices largely invisible when focused only upon privacy of the individual. ${ }^{261}$ The liberty of

256. Carter, 525 U.S. at 90-91. Courts have grappled with how to apply the temporal and affective limitations on which social guests get Fourth Amendment protection. See, e.g., United States v. Williams, 521 F.3d 902, 906 (8th Cir. 2008) (holding that "mere visitors" to another's hotel room have no reasonable expectation of privacy); United States v. Gray, 491 F.3d 138 (4th Cir. 2007) (elaborating that privacy expectations in a commercial setting are less than those of a private, residential setting, and a business guest has less privacy than a social guest); United States v. Rhiger, 315 F.3d 1283 (10th Cir. 2003) (holding that defendant had reasonable expectation of privacy as a social guest in home, which was actually a meth lab, because he knew the owner for two weeks, stayed overnight when he was too drunk to drive, and would enter unannounced to take naps); United States v. Heath, 259 F.3d 522 (6th Cir. 2001) (affirming that defendant had legitimate expectation of privacy in cousin's apartment because he slept there occasionally, he had a key, and he had been accepted into cousin's household).

257. Katz v. United States, 389 U.S. 347, 361 (1967) (Harlan, J., concurring).

258. Georgia v. Randolph, 547 U.S. 103, 111 (2006).

259. Carter, 525 U.S. at 108 (Ginsburg, J., dissenting); see also Gerald G. Ashdown, The Fourth Amendment and the "Legitimate Expectation of Privacy", 34 VAND. L. REV. 1289, 1321 (1981); Eulis Simien, Jr., The Interrelationship of the Scope of the Fourth Amendment and Standing to Object to Unreasonable Searches, 41 ARK. L. REV. 487, 539 (1988).

260. Carter, 525 U.S. at 107 (Ginsburg, J., dissenting).

261. Mary Coombs articulates the problem well: "Its background assumption is one radical individualism rather than one of shared access, trust, and concern. It assumes, absent explicit proof to the contrary, that people do not share. The Court is thus blind to much day-to-day human interaction, and its jurisprudence ignores concerns that grow out of relationships but are not readily articulated." Coombs, supra note 5, at 1631 (citations omitted). 
individuals to live their lives in interpersonal relations of varying degrees of intimacy is nowhere to be found in this Fourth Amendment jurisprudence.

Under the Fourth Amendment, sharing exhibits two general forms of personal vulnerability: the risk that one's words or information will be repeated, and the risk that one's private spaces will be revealed. Both of these risks implicate core values concerning how one chooses to live one's life as an autonomous person in the company of others. But sharing also makes us more secure, allowing us to coordinate our lives with others in ways that are mutually beneficial. James Boyd White suggests that "[p]art of the definition of personal privacy is what might be called social or communal privacy, the interest people have in the security of their arrangements for sharing what they have with others. ${ }^{1362}$ If White is correct, then what we experience as security in our everyday lives is construed by the Supreme Court as a potential vulnerability the State is allowed to exploit.

On the one hand, the privacy protected by the Fourth Amendment depends on how it is conceived by the Supreme Court. So too with assumptions of risk, as Justice Harlan articulated in his dissent in United States $v$. White: "Our expectations, and the risks we assume, are in large part reflections of laws that translate into rules the customs and values of the past and present. ${ }^{1263}$ The more capacious the understanding of privacy under the Katz framework, the greater the burden on government officials to seek judicial approval for their investigative searches.

On the other hand, the privacy we expect depends on our social practices. It would be odd to think that these practices and expectations are always organized around particular conceptions of privacy. Quite the opposite, social practices are more accurately understood as particular ways of obtaining personal fulfillment through shared social life that produce particular conceptions of privacy. Privacy's role in ordinary social practice is fluid and relational. No doubt, privacy sometimes means undisclosed, but not always. If we recognize how our lives are shaped through social practices of sharing, it is odd to equate the fact that "our observable actions and possessions are

262. James Boyd White, The Fourth Amendment as a Way of Talking About People: A Study of Robinson and Matlock, 1974 SUP. CT. REV. 165, 217.

263. United States v. White, 401 U.S. 745, 786 (1971) (Harlan, J., dissenting); see also Smith v. Maryland, 442 U.S. 735, 750 (1979) (Marshall, J., dissenting) ("[W] hether privacy expectations are legitimate ... depends not on the risks an individual can be presumed to accept when imparting information to third parties, but on the risks he should be forced to assume in a free and open society."). Christopher Slobogin, in a similar vein, writes: "Assumption-of-risk reasoning in this context is vacuous, however. We only assume the risks of unregulated government intrusion that the courts tell us we have to assume." SLOBOGN, supra note 4, at 66. 
private at the discretion of those around us" ${ }^{\text {264 }}$ with an actual fact of publicity, at least with regard to all personal relations and transactions. Even when we share with others, we often speak of what is shared as private, and expect that what we share does not become public. In light of the divergence between the juridical and ordinary conceptions of social practice, even as the former purports to rely on the latter, Fourth Amendment doctrine needs an overhaul.

By rendering acts of sharing vulnerable to state intrusion, we risk the State becoming a dominant presence in ordinary life, in ways that conflict with our aspirations to secure the blessings of liberty. These blessings, as we saw in relation to both Laurence v. Texas ${ }^{265}$ and Boy Scouts of America v. Dale, ${ }^{266}$ are secured in the company of others and sometimes for the purpose of expressive association. Articulated in terms of constitutional doctrine, the narrow conception of privacy protected under the Fourth Amendment is in conflict with the due process protection of liberty. ${ }^{267}$

\section{THE FOURTH AMENDMENT AND THE PROBLEM OF SHARED PRIVACY}

Focusing on the relation between a narrow conception of privacy and the person who bears the right, the Court has emphasized the claim that expectations of privacy are personal rights "that must be invoked by an individual." Moreover, the general principle employed is that it is the "individual [who] shares information, papers, or places with another, [and] assumes the risk that the other person will in turn share access to that information or those papers or places with the government..269 The third-party doctrine constructs a particular form of personal identity as an individual, not as a person who inhabits thick intersubjective social relations and forms of life with others. Rather, this jurisprudence protects persons who are conceptually understood to live in social isolation.

While it may be true that individual persons bear constitutional rights, those rights need not apply to individuals only when they are in social isolation from others. In Chief Justice Roberts' analysis of assumed risk through sharing a dwelling, he notes: "To the extent a person wants to ensure that his

264. Georgia v. Randolph, 547 U.S. 103, 133 (2006) (Roberts, C.J., dissenting).

265. 539 U.S. $558(2003)$.

266. 530 U.S. $640(2000)$.

267. Fourth Amendment privacy is also in significant tension with First Amendment protection for free speech necessary for realizing our public, political lives. See Daniel J. Solove, The First Amendment as Criminal Procedure, 82 N.Y.U. L. REV. 112 (2007).

268. Minnesota v. Carter, 525 U.S. 83, 88 (1998).

269. Randolph, 547 U.S. at 128 (Roberts, C.J., dissenting) (emphasis omitted). 
possessions will be subject to a consent search only due to his owm consent, he is free to place these items in an area over which others do not share access and control, be it a private room or a locked suitcase under a bed." ${ }^{270}$ Here we have the image of the hermetically sealed individual, who must share a house with others, but locks his closet, his door, locks his suitcase and hides it under the bed-indeed, locks himself off from others in order to maintain his personal privacy, in order to limit the risk of exposure to the State. According to this construction, in isolation, locked under a bed, we find the freedom of the individual. This vision of privacy is inconsistent with many social practices and with our general expectations of having liberty to share our lives with others free from invasive government intrusion into our interpersonal relationships. This imagery is also at odds with important aspects of our personal and practical lives.

\section{A. Contested Expectations and Social Control}

Justice Douglas warned of the creeping domination of public and private spheres through government surveillance of much of our lives, arguing that the "privacy and dignity of our citizens is being whittled away by sometimes imperceptible steps." ${ }^{271}$ Writing in dissent from the Courts' undercover cases including Hoffa v. United States, ${ }^{272}$ Justice Douglas criticized the willing acceptance of government use of confidants to obtain private information: We live in "a society in which government may intrude into the secret regions of man's life at will.,273 Lamenting the shrinking sphere of life free from government intrusion, he wrote that a time may come "when the most confidential and intimate conversations are always open to eager, prying ears. When that time comes, privacy, and with it liberty, will be gone."

Privacy and liberty will be at an end, as Justice Douglas suggests, because the forms of social life possible under such a surveillance regime will be greatly altered. Fourth Amendment jurisprudence has developed in the face of Justice

270. Id. at 135 .

271. Osborn v. United States, 385 U.S. 323, 343 (1966) (Douglas, J., dissenting).

272. 385 U.S. 293 (1966).

273. Osborn, 385 U.S. at 343 (Douglas, J., dissenting). Justice Douglas also notes that police have been employing peepholes in men's bathrooms and working men's rooms to solicit homosexuals. Id. at 342-43; see David Alan Sklansky, "One Train May Hide Another": Katz, Stonewall, and the Secret Subtext of Criminal Procedure, 41 U.C. DAVIS L. REV. 875, 880 (2008) ("Homosexuality and its policing... were an important part of the background against which the Court constructed the modern constitutional law of the criminal process.").

274. Osbom, 385 U.S. at 354 (Douglas, J., dissenting). 
Douglas's warnings, relying on an account of personal identity and social life that is in significant tension with everyday forms of life.

Let's return to the decision in Minnesota v. Carter. ${ }^{275}$ Here, the holding is that one has no personal expectation of privacy when temporarily in the company of another, at the other's place. Justice Kennedy wrote a separate concurrence, suggesting that some forms of social interaction do preserve expectations of privacy against state intrusion. ${ }^{276}$ Where the social connection is more than "fleeting and insubstantial," Justice Kennedy would likely find a sufficient expectation of privacy. ${ }^{277}$ Justice Kennedy's concurrence was based, in part, on a more nuanced understanding of different forms of social life and their relation to privacy. The majority's mistake is to think that we have, or expect, privacy only when connected to one particular place, the one where we have a bed for the night. ${ }^{278}$ This view ignores the fact that we often have expectations of what Lloyd Weinreb calls "privacy of presence" ${ }^{\text {"279 }}$ - that is, a kind of privacy that we share with others when we are in each others' presence, but nevertheless do not expect to be performing for all the world, and certainly not for state officials.

If Weinreb is right, then the Court applies a very different conception of a shared form of life than the one many of us experience and expect..$^{280}$ No doubt, normative and descriptive expectations concerning privacy can be difficult to assess with empirical accuracy. ${ }^{281}$ Nonetheless, generalizations are possible to the extent that social practices involving interpersonal sharing are common and readily observable. In light of Justice Kennedy's concurrence, as well as Justice Ginsburg's dissent in Carter, it is clear that the Court majority at the very least applies a contested conception of social life. It would seem uncontestable, however, that in keeping the company of others, we often expect a degree of privacy, particularly with regard to state surveillance. We form ourselves as persons, and sustain our identity over time, in part through our shared interactions with others. ${ }^{282}$ For this reason, our lives with others must factor into any conception of constitutional protections and values, lest the

275. 525 U.S. 83 (1998).

276. Id. at 102 (Kennedy, J., concurring).

277. Id.

278. Lloyd Weinreb comments that "the decision in Carter is possibly the most clearly mistaken and the underlying jurisprudence the most inadequate of all the cases decided under the Fourth Amendment in the past thirty years." Lloyd L. Weinreb, Your Place or Mine? Privacy of Presence Under the Fourth Amendment, 1999 SUP. CT. REV. 253, 256.

279. Id. at 267.

280. Id.; see also Coombs, supra note 5 .

281. But see SLOBOGN, supra note 4, at 112-17 (implementing empirical study to assess society's expectations of privacy).

282. See, e.g., GEORGE HERBERT MEAD, MIND, SELF AND SOCIETY (1934). 
Constitution fail to address the actual lives of those it governs. ${ }^{283}$ "We the People" brought the Constitution into effect, and it is the "right of the people," not the right of the person, that the Fourth Amendment secures. If privacy under the Fourth Amendment is too doctrinally stunted to protect our social lives from unwarranted state intrusion, then we have good reason to develop more promising constitutional sources.

What is the harm in failing to protect these forms of social life under the Fourth Amendment? After all, as Chief Justice Roberts suggests, if we wish to keep matters private, we can always keep them secret. ${ }^{234}$ One harm is the greater potential for state control through monitoring and intervention in the forms of social life. As we have seen, Justice Douglas argued that this harm might follow from removing constitutional barriers to pervasive state surveillance. As Professor Jed Rubenfeld has argued: "The danger, then, is a particular kind of creeping totalitarianism, an unarmed occupation of individuals' lives. That is the danger of . . . a society standardized and normalized, in which lives are too substantially or too rigidly directed. ${ }^{, 285}$ Although domination of individual lives is certainly a risk, the problem is not simply one in which government exerts power over the totality of our lives lived in isolation from others. Rather, the problem comes from the disappearance of interpersonal multiplicity. If the others with whom we share our lives are always putative state agents, then we lose the interpersonal relations on which the exercise of our liberty is grounded. Justice Harlan, dissenting from the Court's refusal to apply the Fourth Amendment to undercover agents, reasons that the practice will "undermine that confidence and sense of security in dealing with one another that is characteristic of individual relationships between citizens in a free society." ${ }^{286}$

Turning to Hannah Arendt's political theory, she argues that "[w]ithout a politically guaranteed public realm, freedom lacks the worldly space to make its appearance." ${ }^{287}$ Freedom is experienced in the presence of others, in a shared social space, that through interaction forms the realm of the political. Interpersonal multiplicity is valuable to the realization of liberty because "[t]he life of a free man need[s] the presence of others." ${ }^{\text {288 }}$ Echoing this theme, Justice Douglas, dissenting in United States $v$. White from the expan-

283. See Coombs, supra note 5 , at 1635 ("A view of the world that recognizes the essential interconnectedness of people and the importance of intimacy and sharing is foreign to the atomistic social theory underlying the Court's present doctrine.").

284. See Georgia v. Randolph, 547 U.S. 103, 128 (2006) (Roberts, C.J., dissenting).

285. Jed Rubenfeld, The Right of Privacy, 102 HARV. L. REV. 737, 784 (1989).

286. United States v. White, 401 U.S. 745, 787 (1971) (Harlan, J., dissenting).

287. HANNAH ARENDT, BETWEEN PAST AND FUTURE 149 (1968).

288. HANNAH ARENDT, ON REVOLUTION 31 (1963). 
sion of the assumption of risk doctrine, wrote that "[m]onitoring, if prevalent, certainly kills free discourse and spontaneous utterances. ${ }^{\text {"289 }}$

A structural problem exists here. We can name the problem "totalitarianism." If the State takes the social position of those with whom we share, it eliminates the ability to cultivate our identity and life projects through interaction with others in reciprocal relations with the open possibility of creating new forms of life. ${ }^{290}$ Here the State may dominate identity formation, displacing a multiplicity with a dialectical relation where it figures on both sides-taking the position of the other with whom we interact and setting the terms by which our identity cultivation may occur.

Of course, social interaction, and the social construction of identity, is a form of control too. No doubt, risk already inhabits a person's openness to others. But with interpersonal relations, each person is reciprocally vulnerable to the other. This condition does not exist when the State occupies the position of other. The problem, then, is that the State attempts to control the conditions of an otherwise intimate or associational interaction, with its power to participate as the non-reciprocal other. Individuals need the space to cultivate intimate relationships and the group associations they choose in light of their own life projects, free from a dominating state presence. Perhaps the conditions under which persons choose, and the structure of choice, are each intertwined with social and state mechanisms of control. But, the structures of intersubjective recognition in which we find ourselves nonetheless remain our own. Our expectations of privacy, like the risks we assume, may in part depend on what the Supreme Court construes as protected under the Fourth Amendment. ${ }^{291}$ For this reason, we can insist that constitutional doctrine protect social practice against dominating government intrusions.

Privacy is valued for its protection of autonomy and intimacy. As this Article argued in Parts I.B and I.C, these values are not experienced in isolation from others. We realize our identities as persons only through our interactions with others. Intimacy is one way of acknowledging the ways that others matter to our autonomy, whether manifest in conversation or sexual congress. Once we open ourselves up to others in pursuit of our life goals, however, we assume the risk of state intrusion through the limited privacy protected by the Fourth Amendment. If sharing vitiates privacy, then liberty invites constitutional protections for interpersonal relations.

289. United States v. White, 401 U.S. 745, 762 (1971) (Douglas, J., dissenting).

290. Arendt refers to this condition as "natality." HANNAH ARENDT, THE HUMAN CONDITION 9 (1958).

291. "Our expectations, and the risks we assume, are in large part reflections of laws that translate into rules the customs and values of the past and present." White, 401 U.S. at 786. 
A second harm created by the third-party doctrine is one the Court has already recognized in the First Amendment context. In Boy Scouts of America $v$. Dale, ${ }^{292}$ the Court concluded that forced inclusion of a homosexual member would radically disrupt the Boy Scouts' expression of their identity. Dale was construed as an outsider intruding upon the expressive identity of the group. If the inclusion of Dale disrupted the identity of the Boy Scouts, then it follows that inclusion of state agents within one's social network, within one's confidence, would also disrupt the identities and meaning of our personal relationships and ordinary lives. The Court has taken seriously the idea that social practices and associations have meaning for personal identity. There is therefore a basis for applying that same notion when state officials intrude upon our everyday identity-expressive activities. It is evident then that our form of life is constituted through acts of sharing with particular others-intimate partners, family members, friends, or associates-which we do not intend or expect to become acts of sharing with the world at large.

\section{B. Technology and Social Practice}

These harms directed towards both personal and interpersonal forms of life can be made more concrete by considering how technological progress in the face of the static application of the third-party doctrine may produce new opportunities for state surveillance and intrusion.

Police are now reportedly making regular use of social networking sites such as Facebook and MySpace, posing as regular users in order to learn about criminal activity or to solve crimes. ${ }^{293}$ Under a mechanical application of the third-party doctrine, there would be no Fourth Amendment limitation on agents' ability to employ an alias to learn about criminal activity. Having revealed information about oneself to other persons, one could no longer have an expectation of privacy. The larger the social network, and the more impersonal the interactions, perhaps the less reason there is for concern. One can analogize some social networking activity to actions taken in a public park with a group of friends. A person could not expect the police to shield their eyes from readily-observable public conduct. Not all social networking is relatively more impersonal, however, and not all networking is like playing in the park. When Jane signs up for a social networking service allowing her

292. 530 U.S. $640(2000)$.

293. See Michael Birnbaum, The Profile Police, Campus Officers Cruise Facebook, MySpace for Clues to School-Related Crimes, to Some Students' Chagrin, WASH. POST, Apr. 6, 2009, at A01; Amber Hunt, Detroit Cops to Use Twitter, MySpace, DETROIT FrEE PRESS, May 14, 2009, at 17; Julie Masis, Predators Beware: Face on MySpace May Be Police Decoy, BOSTON GLOBE, Feb. 8, 2009, at Reg3. 
to locate all of her friends, her activity is not easily analogized to playing in the park, and her expectations are not that she has revealed her location to the world at large. This service is meant to provide a relatively closed network of friends who mutually agree to reveal their whereabouts to each other, but not to the world at large. The problem with current Fourth Amendment jurisprudence is that it lacks an ability to draw distinctions among different forms of social interactions, treating the impersonal no differently than the interpersonal.

Even absent Jane's use of a social networking service that enables her and her circle of friends to monitor each other's location, her cell phone is itself a tracking device. ${ }^{294}$ Jane regularly reveals her location to her cell phone provider as a necessary complement to having cell phone service. State agents have increasingly turned to this information to monitor the movements of suspects and to track persons whom they wish to arrest. ${ }^{295}$ Given the prevalence of cell phone use, many persons carry with them their own personal tracking devices, leaving an electronic trail of everywhere they have been and where they are presently going. Police engaged in narcotics investigations can tell whether a person has gone to an area known for drug trafficking. Police can determine whether an individual has visited the home of someone on a terrorist watch list. Once Jane becomes a person of police interest, she may further implicate herself merely from the places she visits and the persons with whom she associates. ${ }^{296}$ Police may learn of these places and persons without

294. It is also itself a source of considerable content about her life, especially if her phone is an iPhone containing email, pictures, and electronic documents. For consideration of the Fourth Amendment implications of police searches of cell phone content pursuant to searches incident to arrest, see Adam M. Gershowitz, The iPhone Meets the Fourth Amendment, 56 UCLA L. REV. 27 (2008).

295. See United States v. Forest, 355 F.3d 942, 949-50 (6th Cir. 2004) (stating that cell site data is not a Fourth Amendment violation unless the defendant's phone is located somewhere where the defendant has an expectation of privacy); In re the Matter of the Application of the United States for an Order Directing a Provider of Elec. Commc'n Serv. to Disclose Records to the Gov't, 534 F. Supp. 2d 585, 613 (W.D. Pa. 2008) ("[W]ithout a warrant based on probable cause the Government may use a tracking device to ascertain an individual's location on a public highway but not in a private home...."); In re Application of United States for an Order for Prospective Cell Site Location Info. on a Certain Cellular Tel., 460 F. Supp. 2d 448, 462 (S.D.N.Y. 2006) (supporting the proposition that the government could run afoul of the Karo Rule (monitoring of a beeper in a private residence with no visual surveillance violates the Fourth Amendment), by using cell site information to conduct surveillance of a target in a private home that could not be observed from public spaces). Courts have also confronted suppression motions from government agents' use of cell cite information in unpublished opinions. See, e.g., United States v. Skinner, No. 3:06-CR-100, 2007 WL 1556596 (E.D. Tenn. May 24, 2007); United States v. Bermudez, No. IP 05-43-CR-B/F, 2006 WL 3197181, (S.D. Ind. June 30, 2006).

296. See David Cole, Hanging With the Wrong Crowd: Of Gangs, Terronists, and the Right of Association, 1999 SUP. CT. REV. 203, 205 (arguing that guilt by association "erode[s] constitutional protection of the right of association, and warrant[s] a reconsideration of the right's purpose in a democratic society"); see also Katherine J. Strandburg, Freedom of Assaciation in a Networked World: 
having to engage in the laborious task of maintaining visual surveillance of Jane's movements or seek a warrant backed by probable cause.

Depending on the quality of information, and the location of the suspect, police may implicate Fourth Amendment protections, despite a mechanical application of the third-party doctrine or a public-streets rationale. ${ }^{297}$ Courts have been hesitant to allow warrantless use of such information when the technology reveals a person's location in a protected space, such as the home. ${ }^{298}$ Despite Katz $v$. United States's ${ }^{299}$ imperative that the Fourth Amendment protects people, not places, ${ }^{300}$ the Court has been particularly solicitous to protect people only in particular places. Social life is lived in the company of others in a myriad of places. If the home is the only limitation on official use of cellular tracking information, most of everyday life for most people will be lived in placesoutside the home-that themselves receive little or no Fourth Amendment protection. Taking Katz's injunction seriously, in the context of interpersonal relations and shared social life, will require carefully rethinking the boundaries of Fourth Amendment protection.

Foremost among the boundaries to be reconsidered is the Supreme Court's failure to acknowledge the harms police cause when they invade social gatherings, protected by a rule of third-party standing. If the police discover wrongdoing by Jane's friend John while invading the home of his intimate friend Jane, in violation of the Fourth Amendment, John has no constitutional shield, despite the intrusion. ${ }^{301}$ Perhaps we do not alter our social lives in light of this risk, but the freedom from state intrusion into intimate parts of our lives should not be predicated on our willingness to alter our behavior. Indeed, despite the risks of exposure, people have been flocking to internet social networking sites. Nonetheless, unregulated police intrusion into social relations risks harm to both individual autonomy and meaningful association.

The question is whether new forms of social life enabled by technological advances will confront static Fourth Amendment doctrine. Can we reconceptualize existing doctrine, to renew constitutional commitments to protect spheres

First Amendment Regulation of Relational Surveillance, 49 B.C. L. Rev. 741 (2008) (discussing government use of "relational surveillance" to monitor social networks).

297. See Renee McDonald Hutchins, Tied Up In Knotts? GPS Technology and the Fourth Amendment, 55 UCLA L. REV. 409 (2007).

298. See United States v. Karo, 468 U.S. 705 (1984); United States v. Knotts, 460 U.S. 276, 283-84 (1983); In re United States, 534 F. Supp. 2d at 613 ("[W]ithout a warrant based on probable cause the Government may use a tracking device to ascertain an individual's location on a public highway but not in a private home....").

299. 389 U.S. 347 (1967).

300. Id.

301. See Rakas v. Illinois, 439 U.S. 128 (1978). 
of interpersonal life $?^{302}$ In light of the emphasis Laurence v. Texas ${ }^{303}$ places on protecting liberty in interpersonal contexts, the next section suggests ways of moving from a static view of privacy to a more nuanced view of liberty.

\section{LIBERTY UNDER THE FOURTH AMENDMENT: A SUBSTANTIVE INQUIRY}

When we recognize that shared relationships with others are "central to any concept of liberty, ${ }^{, 304}$ as the Supreme Court has made clear, the analytic distinction between what is private and what is public becomes practically less important, and conceptually less useful. In keeping relationships free from the dominating presence of government intrusion, Laurence $v$. Texas's conception of liberty applies to government searches no less than to criminal statutes. Just as the government may not demean particular relationships "or control their destiny by making their private sexual conduct a crime, ${ }^{, 305}$ the Constitution should not allow government officials to exploit the vulnerability of those relationships, particularly for suspicionless investigative purposes.

Fourth Amendment jurisprudence should be refocused in light of the protections provided interpersonal liberty. To do otherwise would fail to secure the Constitution's promise of liberty, in areas of our lives where government domination is most invasive. To overcome the conflict by limiting the scope of Laurence would ignore social practices of interpersonal sharing. Moreover, like Justices Holmes and Brandeis' call for greater First Amendment protection, which flowered into a robust defense of free speech, ${ }^{306}$ Fourth Amendment jurisprudence has countervailing precedents for protecting our interpersonal lives, on which a future Court may draw. ${ }^{307}$ Foremost among them are the

302. Writing in dissent in United States $v$. White, Justice Douglas warned of the kind of problem cell cite tracking creates, asserting that

the concepts of privacy which the Founders enshrined in the Fourth Amendment vanish completely when we slavishly allow an all-powerful government, proclaiming law and order, efficiency, and other benign purposes, to penetrate all the walls and doors which men need to shield them from the pressures of a turbulent life around them.

401 U.S. 745, 756 (1971) (Douglas, J., dissenting).

303. 539 U.S. $558(2003)$.

304. Roberts v. U.S. Jaycees, 468 U.S. 609, 619 (1984).

305. Laurence, 539 U.S. at 578.

306. See Gitlow v. New York, 268 U.S. 652, 672-73 (1925) (Holmes, J., dissenting); Abrams v. United States, 250 U.S. 616, 630 (1919) (Holmes, J., dissenting); see also Whitney v. California, 274 U.S. 357, 372 (1927) (Brandeis, J., concurring).

307. See Minnesota v. Carter, 525 U.S. 83, 106-09 (1998) (Ginsburg, J., dissenting); White, 401 U.S. at 768-69 (Harlan, J., dissenting); Osborn v. United States, 385 U.S. 323, 340 (1966) (Douglas, J., dissenting). 
connections between personal security and liberty from the Court's early and important decision in Boyd v. United States ${ }^{308}$ :

The principles laid down in this opinion affect the very essence of constitutional liberty and security.... [T] hey apply to all invasions on the part of the government, and its employees of the sanctity of a man's home and the privacies of life. It is not the breaking of his doors, and the rummaging of his drawers, that constitutes the essence of the offense; but it is the invasion of his indefeasible right of personal security, personal liberty and private property ...."309

In this early attempt to articulate the values protected by the Fourth and Fifth Amendments, the Court recognized that the "very essence of constitutional liberty and security" was at stake. Justice Brandeis, drawing on Boyd, also emphasized the import of liberty when it came to government intrusion upon shared communications. He wrote, "Decency, security and liberty alike demand that government officials shall be subjected to the same rules of conduct that are commands to the citizen." 310

Perhaps it was a conceptual mistake for the Warren Court to call what the Fourth, Fifth, Ninth, and Fourteenth Amendments protect "privacy.",11 Employing privacy tempts us to establish a conceptual opposition with publicity, and to protect as private only that which is not public. Privacy has been construed as secrecy and solitude, the keeping to oneself in the company of no other. As we have seen, however, privacy and publicity do not neatly form a paired opposition. ${ }^{312}$ When we share our lives with others in intimacy, we no longer live in complete privacy, though it could hardly be said that we have exposed ourselves to the public. Since the liberty protected in the Constitution is more than a right against its procedural deprivation, then what is at stake through all these Amendments is not only the implicit notion of privacy, but the explicit protection of liberty. Accordingly, the Fourth Amendment is as easily read to protect the liberty of individuals against unwarranted government intrusion at home as it is to protect the liberty of individuals in public. By protecting privacy, the Fourth Amendment shares with due process the important task of protecting an essential aspect of liberty. Liberty thrives only when government does not play a dominant role in our interpersonal lives-a principle echoed in both theory and practice. The commitment to liberty in the Constitution's Preamble, and by implication in the Fourth Amendment,

308. 116 U.S. $616(1886)$.

309. Id. at 630 .

310. Olmstead v. United States, 277 U.S. 438, 485 (1928) (Brandeis, J., dissenting).

311. Griswold v. Connecticut, 381 U.S. 479 (1965).

312. See infra Part I. 
is a commitment collectively shared by the people, and intergenerationally preserved ${ }^{313}$ The persons, houses, papers, and effects the Fourth Amendment secures are essential features of ordinary life lived free from state domination. ${ }^{314}$

If the Fourth Amendment is going to provide protection against state intrusion relevant to modern forms of life, it must draw on other constitutional values. Indeed, search and seizure doctrine has not always been tethered to privacy alone. Robust constitutional criminal procedure owes its doctrinal development to questions concerning "the very essence of a scheme of ordered liberty. ${ }^{\text {"15 }}$ Considering whether criminal procedure protections were sufficiently fundamental to warrant application to the states required the Court to ask whether a right is one of the "fundamental principles of liberty and justice which lie at the base of all our civil and political institutions." ${ }^{316}$ Most constitutional criminal procedure provisions have been applied to the states precisely because of their fundamental role in safeguarding liberty. ${ }^{317}$ The Court applied the exclusionary rule to the states, initiating the modern development of the Fourth Amendment, in order to vindicate the "freedom implicit in the concept of ordered liberty. ${ }^{\text {"318 }}$ Fourth Amendment jurisprudence has august roots in protecting liberty.

The claim that the Fourth Amendment protects privacy, narrowly construed, is deeply embedded in Fourth Amendment jurisprudence. Therefore, disentangling privacy is not an easy task. Yet, it is simultaneously true, as the Laurence Court makes clear, that "lliberty protects the person from unwarranted government intrusions into a dwelling or other private places." ${ }^{319}$ As an initial

313. On the importance of the intergenerational constitutional project, see Bruce Ackerman, The Living Constitution, 120 HARV. L. REV. 1737 (2007).

314. Arguing that the Fourth Amendment text specifically provides for a "right of the people to be secure" in their houses, persons and belongings, Rubenfeld concludes that the focus on privacy has obscured the Fourth Amendment's "distinctive political valence." Rubenfeld, supra note 20, at 117. Moreover, he argues that Fourth Amendment jurisprudence should focus on the right to security, which the constitutional text explicitly protects. The Fourth Amendment harm to be avoided "is the stifling apprehension and oppression that people would justifiably experience if forced to live their personal lives in fear of appearing 'suspicious' in the eyes of the state." Id. at 127. That political valence secures shared personal life from state domination. Security, however, is not an end in itself, related though it may be to protecting features of ordinary life. Security is above all valued for its relation to the Constitution's commitment to "secure the blessings of liberty." U.S. CONST., pmbl. The Preamble makes clear that security is a value related to liberty, not just of the individual, but to "ourselves and our Posterity." Id.

315. Palko v. Connecticut, 302 U.S. 319, 325 (1937).

316. Powell v. Alabama, 287 U.S. 45, 67 (1932).

317. See, e.g., Duncan v. Louisiana, 391 U.S. 145 (1968) (holding that the Sixth Amendment right to jury trial applies to states); Malloy v. Hogan, 378 U.S. 1 (1964) (holding that the Fifth Amendment right to be free from compelled self-incrimination applies to states).

318. Mapp v. Ohio, 367 U.S. 643, 655 (1961) (internal quotations omitted).

319. Lawrence v. Texas, 539 U.S. 558, 562 (2003) (emphasis added). 
matter, if the privacy (narrowly construed) that the Fourth Amendment protects would allow a particular kind of government intrusion, it does not follow that the liberty protected by the Fourth Amendment need also permit the intrusion. Just as the protections afforded intimate relations diverge between the liberty due process protects and the privacy the Fourth Amendment protects, it is plausible to conclude that the liberty the Fourth Amendment protects may diverge from the privacy it protects. Thus, when the Court reasons that if a person knowingly shares information or a dwelling with another, and that she no longer has an expectation of privacy, the same act of sharing might not defeat liberty as protected under a new Fourth Amendment doctrine that draws on due process conceptions of liberty. Fourth Amendment privacy and the liberty ordinarily protected under due process may overlap, and the former may be valued for its ability to foster the latter, but the two need not always coincide. Thus, if the Fourth Amendment is understood to protect liberty as well as privacy, new constitutional possibilities emerge for shielding interpersonal relations from state intrusion.

Analogical reasoning has its limits. Critics may point to the different purposes for the movement from privacy to liberty under due process jurisprudence than for the protection of privacy under the Fourth Amendment. Might this Article's argument risk a simplistic nominalism regarding the use of "privacy" in each of these constitutional contexts? No doubt, Laurence protects against a state criminal law being used to demean the lives of homosexuals, whereas the Fourth Amendment places limits on searches and seizures. In this respect, the limitations imposed by each doctrine operate on different objects. In another respect, however, each seeks to protect a similar sphere of private, interpersonal life from state intrusion. Laurence begins with this unifying theme in it's opening sentence- "Liberty protects the person from unwarranted government intrusions into a dwelling or other private places[ $]^{\prime 320}$ — which could just as easily have been written as the beginning to a Fourth Amendment opinion. This conceptual commonality creates the impetus to urge doctrinal development. Protecting privacy may be bedrock Fourth Amendment doctrine, but securing liberty is no less fundamental a purpose. Liberty may protect practices of interpersonal sharing where privacy under the third-party doctrine would not.

\section{A. Doctrinal Developments}

Fourth Amendment inquiry is therefore incomplete. When an individual broadcasts to the world information about herself it may be fair to say that 
she has made the information public to some extent, and a government official, like any other member of the public, may legitimately take notice. In this sense, the individual has knowingly exposed to the public that information. But even if privacy would be defeated by exposing information to another person (a single member of the viewing public), it does not follow that liberty protected by due process would be defeated by sharing one's life within interpersonal relations. The additional analytic step the Court must take in light of Laurence is to inquire into the nature of the relationship in which the sharing occurs. If it is a relationship protected by the liberty of the Due Process Clause, then despite the relationship's public nature, greater protection is warranted.

Law is no stranger to privileging or punishing persons because of their relationship status. ${ }^{321}$ Courts regularly provide testimonial privileges designed to protect the confidentiality and intimacy of particular kinds of relationships. Professional relationships such as the attorney-client relationship receive testimonial privilege because of the value to the legal system of preserving confidential communications. ${ }^{322}$ Spousal relationships merit testimonial privilege because the State recognizes the fundamental, prepolitical value of protecting the integrity of a trusting marital relationship, free from official compulsion. ${ }^{323}$ Not all worthy relationships receive these benefits, however. Loving, but non-marital, relationships are denied the privilege, as are other forms of friendship. ${ }^{324}$ Nonetheless, courts regularly acknowledge the importance of some interpersonal relations when determining whether or when a person may claim a privilege against a compulsion to testify. Inquiring into the nature of a relationship to determine whether a particular rule of law applies is not a novel practice.

The procedural Fourth Amendment needs substantive augmentation. A substantive Fourth Amendment inquiry would require the Court to attend to the nature of the relationship implicated in the analysis of privacy. Justice

321. For a systematic exploration of the ways criminal law privileges and punishes individuals based on their family status, see DAN MARKEL, JENNIFER M. COLLINS \& ETHAN J. LEIB, PRIVILEGE OR PUNISH: CRIMINAL JUSTICE AND THE CHALLENGE OF FAMILY TIES (2009).

322. See Upjohn v. United States, 449 U.S. 383, 389 (1981) (recognizing the need for "full and frank communication between attorneys and their clients").

323. See Trammel v. United States, 445 U.S. 40, 44 (1980) ("The modern justification for this privilege against adverse spousal testimony is its perceived role in fostering the harmony and sanctity of the marriage relationship.").

324. See Sanford Levinson, Testimonial Privileges and the Preference of Friendship, 1984 DUKE LJ. 631, 645 ("If we are so willing to recognize the importance of intimate relationships when they are spousal, why not recognize them in other contexts as well, such as those between lovers, friends, or family?"). 
Harlan, writing in dissent in United States $\nu$. White, ${ }^{325}$ argued for a similar substantive Fourth Amendment inquiry:

Since it is the task of law to form and project, as well as mirror and reflect, we should not, as judges, merely recite the expectations and risks without examining the desirability of saddling them upon society. The critical question, therefore, is whether under our system of government, as reflected in the Constitution, we should impose on our citizens the risks of the electronic listener or observer without at least the protection of a warrant requirement. ${ }^{326}$

Requiring warrants for valid searches places pressure on the Court to narrow the domain of privacy and thereby expand the range of unconstrained police action. If a search does not invade privacy, then no warrant is required. A substantive approach, by contrast, would afford a stronger legal basis for protecting interpersonal relations otherwise unprotected under current doctrine. But what does this substantive addendum entail?

When the relationship is one that the Constitution protects under the liberty of the Fifth or Fourteenth Amendments, an additional Fourth Amendment inquiry should apply. The Court may continue to ask (1) whether something has been knowingly exposed to the public - that is, whether we have a reasonable expectation of privacy. As we have seen, however, when the public can be comprised of a single other person with whom one shares one's life, privacy is easily defeated. Accordingly, the Court's usual inquiry must be supplemented. The Court must also ask (2) what is the nature of the relationship in which the item was shared or exposed. If the relationship is of a kind protected under due process, then the Court should determine (3) whether the intrusion interferes with or constitutes a dominant presence in the relationship. If the government action interferes with a protected relationship, then the government's actions must be justified at the outset under default rules of Fourth Amendment procedure. If the relationship is impersonal or otherwise not protected by due process, then state agents are free to intrude just as they are under the current third-party doctrine. ${ }^{327}$ Moreover, if state intrusion occurs at the initiative or invitation of a third party, then the intrusion does not impermissibly interfere with a protected relationship.

Under the Katz framework, whether an individual has an expectation of privacy determines whether a search occurred in the first place. The Fourth Amendment provides protection only against unreasonable searches. Thus, if

325. 401 U.S. 745 (1971).

326. Id. at 786 (Harlan, J., dissenting).

327. See, e.g., id. at 749 (majority opinion) ("II]nescapably, one contemplating illegal activities must realize and risk that his companions may be reporting to the police."). 
a court determines that police actions did not intrude upon a reasonable expectation of privacy, then there is no search, and thus no constitutional interest to protect. By extending the analysis of privacy to include the possibility that one might still have privacy in public - in shared interpersonal relationshipswe have merely extended the inquiry into situations in which the Fourth Amendment may apply. ${ }^{328}$

Ordinarily, the claim that something is private does not defeat a government agent's interest in searching the item. Instead, it merely requires the agent to comply with minimal constitutional procedures of obtaining a warrant supported by probable cause from a neutral magistrate, ${ }^{329}$ or to have articulable suspicions at the outset of a temporary stop and frisk. ${ }^{330}$ Moreover, the warrant requirement itself is defeasible under exigent circumstances or upon the showing of a special need. ${ }^{331}$ Substantive protection for liberty under the Fourth Amendment merely requires reasonable forms of police investigative action. Whereas Laurence sets a high bar to state criminalization of conduct that is constitutive of an intimate relation, a substantive Fourth Amendment doctrine would provide additional occasions to protect against unwarranted police incursions into interpersonal relationships.

\section{B. Applications}

The majority's view in Georgia थ. Randolph $h^{332}$ was that social expectations did not allow police to act on the consent of one resident over the physically present objection of another. Chief Justice Roberts argued in dissent that the majority's approach is too fine and formalistic a line to draw. He remarked, "Usually when the development of Fourth Amendment jurisprudence leads to such arbitrary lines, we take it as a signal that the rules need to be rethought." ${ }^{333}$ Indeed, we do need to rethink Fourth Amendment jurisprudence in light of

328. Others have argued that the Court should broaden its definition of searches so as to bring more police conduct within the Fourth Amendment. See Brian J. Serr, Great Expectations of Privacy: A New Model for Fourth Amendment Protection, 73 MINN. L. REV. 583 (1989); Stuntz, supra note 213, at 1056 (noting that "consistent privacy protection requires a much broader definition of Fourth Amendment searches than the Court has adopted").

329. See Mincey v. Arizona, 437 U.S. 385, 390 (1978).

330. See Terry v. Ohio, 392 U.S. 1 (1968).

331. It is likely, under this approach, that there would be a growth in special-needs claims-a prospect that regulates police actions according to a Fourth Amendment standard, rather than concluding that no search occurred in the first place. See, e.g., Illinois v. Lidster, 540 U.S. 419, $427-$ 28 (2004) (checkpoint for information gathering); Mich. Dep't of State Police v. Sitz, 496 U.S. 444, 455 (1990) (highway sobriety checkpoints); United States v. Martinez-Fuerte, 428 U.S. 543, 545, 551-53 (1976) (searches near the Mexican border).

332. 547 U.S. 103 (2006).

333. Id. at 137 (Roberts, C.J., dissenting). 
its conflict with the liberty protected by due process, not to achieve the outcome the Chief Justice seeks, but to develop a rule more consistent with the intersubjective understanding of privacy as a central feature of human liberty. Applying this new analytic approach would, for example, strengthen the Court's majority opinion in Randolph. ${ }^{334}$

Rather than requiring the presence of the nonconsenting spouse to prevent a warrantless search of the home, Fourth Amendment inquiry would ask what is the nature of the relation affected by the intrusion. The relationship between husband and wife is a paradigm case of a protected relationship. Here, however, the police were invited to the scene by the wife. If the police intrusion went no further than protecting against domestic violence, the wife's invitation would have vitiated all further Fourth Amendment concerns the husband might raise. If the husband were not present, then police intrusion regarding any other matter would flow from the initiative and invitation of the wife as a third-party informant. In this case, the invitation to search the premises for evidence of the husband's drug possession did not readily follow from the invitation to intervene in a domestic dispute. Although police intervention in a domestic dispute is clearly justified by the wife's call for help, narcotics possession was not connected to the primary purpose of the police presence at the wife's invitation. Nor was the husband otherwise the subject of a narcotics investigation.

The difficulty in this case emerges from the clash between the wife's consent and the husband's refusal to consent to a search unrelated to the initial invitation for the police to intervene. If we view the two possible outcomesvindicate the wife's consent or recognize the husband's refusal-through the lens of the dissent's proposal, the choice becomes clearer. Recall that Chief Justice Roberts relies on the third-party assumption-of-risk analysis to conclude that if someone wants to shield items from a police search he must place the items in a "private room or a locked suitcase under a bed," 335 where no others have shared access. Under this approach, the husband assumed the risk that his wife would invite the police to search his stash.

The majority, by contrast, concluded that a warrantless search "over the express refusal of consent by a physically present resident cannot be justified as reasonable as to him on the basis of consent given to the police by another resident." ${ }^{336}$ The husband expressly refused consent and the police had no other independent reason to investigate further. If the police intruded into the home

335. Id. at 135 (Roberts, C.J., dissenting).

336. Id. at 120 (majority opinion). 
in this situation, they would have dominated a protected relationship. This case is particularly difficult because there is no evidence that the police actively sought consent for this search-the wife is the one who requested police intervention. The protected relationship here was already in distress, independent of any state involvement. Absent further reasons to act, however, prioritizing the wife's consent over the husband's refusal would exploit a vulnerable relationship and intrude on a protected liberty interest. The state's interest here is not the prevention of harm, but the gathering of evidence against a person they otherwise did not suspect of criminal wrongdoing. In this narrow and contextually specific situation, adhering to a firm and bright line around a protected relationship is as important as maintaining a line at the threshold of the home. Thus, the Court settled on the reasonable rule that would require a warrant where the person targeted by the search was present and did not consent to the search. Importantly, this rule relies on a substantive inquiry into the nature of the relationship that the police sought to invade.

What about when the person targeted is not present? May the police seek consent from personal relations if consent would unlikely be forthcoming from the search's target? When police initiate the interaction, the fact that the dwelling is shared may defeat privacy, but does not end the substantive Fourth Amendment inquiry. Police must ask the nature of the relation from which they seek consent, and must ask whether seeking such consent would constitute an undue interference or dominant presence. Recall the facts of United States v. Matlock. ${ }^{337}$ With the suspect safely deposited in the back of a police cruiser, three officers went to the front door of the home seeking consent to search from the suspect's domestic partner. In this situation, substantive Fourth Amendment inquiry demands more from the police. In Matlock, the police would have needed either to get Mr. Matlock's consent or a warrant. They would not have been able to stand on the porch in force and obtain consent from his girlfriend. ${ }^{338}$ Although third-party consent is ordinarily a "get out of the Fourth Amendment free" card for the police, here the police and courts will have to judge whether reliance on third parties invades and exploits the vulnerability of protected interpersonal relationships. When police initiate contact with a person's close personal and intimate relations, seeking consent from one to search for evidence of another, Fourth Amendment protections secure the targeted person's underlying liberty right. If there is an interpersonal relationship that involves shared occupancy of a home, and the

337. 415 U.S. 164 (1974).

338. Id. at 171. 
target of a search is not present, the police ordinarily may not rely on obtaining consent to search from the nontargeted person.

This limitation applies to contact initiated by police for the purpose of eliciting consent to search. Persons remain free to voluntarily repeat to state officials claims they have heard, actions they have seen, or information they possess. Constitutional protections do not extend to the voluntary choices of others to repeat what one says or does. In this, we truly assume the risk.

This risk, however, is consonant with the one we assume in the Sixth Amendment context. When our Sixth Amendment right to counsel applies, police may not actively seek information from our conversations with others. ${ }^{339}$ However, state agents may be the passive recipients of our willingness to talk, or the willingness of others to repeat what we say. ${ }^{340}$ This distinction is one already embedded in constitutional criminal procedure, and should occasion no practical problems in the context of interpersonal relations protected by the Fourth Amendment.

Justice Kennedy's concurrence in Minnesota थ. Carter ${ }^{341}$ is important for how it frames the central issue in terms of the interpersonal relationship's nature. Justice Kennedy claims "that almost all social guests have a legitimate expectation of privacy, and hence protection against unreasonable searches, in their host's home." ${ }^{342}$ Not all social guests receive privacy protection, because not all social guests have the kind of connection to the host and home that forms "the center of the private lives of our people." ${ }^{343}$ What then is the right kind of connection? One must establish a "meaningful tie or connection to the owner, the owner's home, or the owner's expectation of privacy." 344 Such a meaningful connection is not a "fleeting and insubstantial" one, writes Kennedy. ${ }^{345}$ Thus, for Justice Kennedy, the protected value of shared privacy requires considering the nature of the underlying interpersonal relationship. Where guests use the host's home as a fleeting place to transact business, they have no meaningful relationship with the host. The relationship does not form part of the liberty protected by either due process or the Fourth Amendment. Accordingly, consistent with his opinion in Lawrence $v$. Texas, ${ }^{346}$ Justice Kennedy emphasizes the role that the personal relationship plays in garnering

339. See United States v. Henry, 447 U.S. 264 (1980); Massiah v. United States, 377 U.S. 201 (1964).

340. See Kuhlmann v. Wilson, 477 U.S. 436 (1986).

341. 525 U.S. 83 (1998).

342. Id. at 99 (Kennedy, J., concurring).

343. Id.

344. Id. at 102.

345. Id.

346. 539 U.S. $558(2003)$. 
constitutional protections for interpersonal social practices vital to the realization of liberty. Substantive inquiry into the nature of interpersonal relations is therefore possible under the Fourth Amendment. It is already part of Justice Kennedy's analytic approach, and implied by the majority's approach in Randolph.

Where there is an interpersonal relationship, not a fleeting co-occupation of physical space, the police would either have to obtain consent from all the targeted individuals, or seek a warrant-unless another Fourth Amendment exception such as exigent circumstances applied. ${ }^{347}$ Recall that Justice Ginsburg wrote in her Carter dissent that "[h]uman frailty suggests that today's decision will tempt police to pry into private dwellings without warrant." ${ }^{348}$ They may still be tempted. They will have to satisfy themselves first that the relationship into which they wish to intrude is not protected under due process. The protection of social guests would deserve more attention, as Justice Kennedy intimated. Since having social guests forms part of ordinary life, police intrusion into such social practices would risk becoming a dominating presence in our ordinary lives. A substantive Fourth Amendment inquiry would likely direct police into default probable-cause procedures and away from reliance on the thirdparty doctrine.

Likewise, in third-party doctrine cases such as Illinois v. Rodriguez, ${ }^{349}$ involving the apparent consent of Mr. Rodriguez's former domestic partner, police would ordinarily be able to rely on third-party consent to search the targeted individual's dwelling without a warrant. In that case, the Court held that the police acted reasonably when they relied on Gail Fischer's claim that she had authority to consent to a search of her former boyfriend's apartment. ${ }^{350}$ Insofar as Ms. Fischer's consent exploited her relationship to Mr. Rodriguez, there is cause for concern. Because the police did not initiate contact or seek an opportunity to search, Ms. Fischer is like any other citizen wishing to report criminal activity. Yet, unlike any other citizen, she had shared a protected relationship with the search's target. Since the relationship had already ended, and because Ms. Fischer initiated police involvement, there is a smaller risk that the intrusion risks dominating a protected relationship.

As we move outward from the intimate associations that center around the home, the proposed rule becomes less applicable. In cases such as Lewis v. United States, ${ }^{351}$ the police do not intrude into a protected relationship by

348. Carter, 525 U.S. at 108 (Ginsburg, J., dissenting).

349. 497 U.S. 177 (1990).

350. Id. at 183 .

351. 385 U.S. 206 (1966). 
having an agent transact business with the person under suspicion. Cases such as Hoffa v. United States, ${ }^{352}$ which involved a state agent placed in the private confidence of a targeted individual, become more difficult. When a government informant is placed among a mixture of close business associates and friends, the nature of the relationship becomes less clear. Such informants can become particularly vexing when they invade not only close personal relationships, but also when they implicate protected civic and political associations. In such cases, courts may have to conduct a more fine-grained analysis to determine if liberty interests are implicated in the manner suggested by Justice Kennedy's Carter concurrence. The principle, however, would remain the same: Government may not intrude without invitation into protected interpersonal relations without a warrant or an established exception to the warrant requirement. Whether the nature of the relationship at stake in cases like Hoffa is more fleeting and less protected will require case by case analysis.

My proposed doctrinal addendum may be unlikely to change many outcomes in third-party cases. Randolph was rightly decided; Matlock wasn't. Rodriguez would pass muster, but another Carter may not. Specific doctrinal outcomes are not the whole story, or even the main plot. When we focus on privacy as we do in third-party cases, we fail to examine the extent to which a search invades a protected sphere of liberty. Our focus on privacy has obscured the independent importance of liberty. The two often overlap, but not always.

Reorienting Fourth Amendment inquiry in cases of social sharing creates three beneficial effects. First, the Fourth Amendment would view interpersonal relations as having protected constitutional value. On balance, particular intrusions may often be justified. Yet, in arriving at those conclusions, courts would at least have contemplated the possibility of protecting interpersonal relations under the Fourth Amendment. Doctrine focused only on expectations of privacy fails to even recognize value in protecting interpersonal relations. Second, the Fourth Amendment would provide some protection against policeinitiated consent requests that exploit interpersonal relations. If the state targets individuals through their associations, then the state must follow ordinary Fourth Amendment procedures. Third, courts would have a new analytic framework in which to confront issues that will inevitably arise over new social networking technologies and practices. Current Fourth Amendment doctrine provides few privacy protections and little analytic guidance.

Returning to our initial example, if Jane wishes to share information with her social network of friends, the police must obtain a warrant in order to intrude upon her trust. The fact that she trusts others cannot be the occasion 
for the state to invade her interpersonal relations. As technology provides additional ways to stay connected with friends and family-ways of sharing private and personal life with chosen others - the third-party doctrine unreconstructed will render social life vulnerable to forms of state domination. If the Fourth Amendment remains static, the third-party doctrine will render privacy consistently vulnerable to technological changes. By contrast, a reconstructed Fourth Amendment may provide a fecund ground to protect interpersonal liberty in a networked world.

It is beyond the scope of this Article to anticipate all the ways a reoriented Fourth Amendment analysis might develop. It is enough to recognize the need for Fourth Amendment doctrine to protect due process interests in the liberty to share interpersonal relationships free from unwarranted government encroachment. No doubt, the proposed substantive consideration of the underlying relationship may inconvenience police. Justice Stevens reminds us, however, that "[e]ven if the warrant requirement does inconvenience the police to some extent, that fact does not distinguish this constitutional requirement from any other procedural protection secured by the Bill of Rights. It is merely a part of the price that our society must pay in order to preserve its freedom." ${ }^{353}$

\section{CONCLUSION}

Constitutional law is capacious in scope, and interstitial in practice. Much constitutional discussion focuses on the narrow doctrinal issues surrounding specific clauses. John Hart Ely made this critique commonplace, calling the problem one of "clause-bound interpretation." W34 When we look more broadly at the Constitution, however, we see repeating themes and motifs. Privacy, of course, is one of these themes, though not explicitly named in constitutional text. Both the Fourth Amendment and the Due Process Clauses of the Fifth and Fourteenth Amendments protect privacy, though they do so under doctrinal frameworks responding to different institutional pressures and social settings. The privacy due process protects emerges in interpersonal situations-marriage, family, intimate relationships, and procreation. In Laurence $v$. Texas, ${ }^{355}$ we learn further that the liberty secured by due process does not only protect the person in isolation, but also protects personal relationships. Nonetheless, the privacy protected by the Fourth Amendment excludes the privacy we experience in public when we share our lives with

353. Califomia v. Acevedo, 500 U.S. 565, 601 (1991) (Stevens, J., dissenting).

354. JOHN HART ELY, DEMOCRACY AND DISTRUST: A THEORY OF JUDICLAL REVIEW 12 (1980).

355. 539 U.S. $558(2003)$. 
others. Interpersonal relations constituted through acts of sharing conversations, information, and our homes render us vulnerable to the State because the Supreme Court construes such acts of sharing as risks we assume in making public aspects of our lives. This doctrine misconstrues social practice and fails to recognize the liberty Laurence protects as a right to associate with others through interpersonal relations free from state intrusion. From the opening sentences, Laurence reads like a Fourth Amendment case decided under due process analysis. Justice Kennedy juxtaposes the protection liberty affords "a dwelling or other private places" with "other spheres of our lives and existence" that include "certain intimate conduct." capacities for government to dominate our lives, a place to draw a firm but bright line is not only at the threshold of the home, ${ }^{357}$ but also around the interpersonal relations essential to realizing our constitutionally protected liberties. If we are to secure ordinary social life against the risk of stifling government intrusion, we must refocus constitutional attention away from privacy narrowly construed by the third-party doctrine and towards the liberty protected in Laurence. As Justice Kennedy suggests, we must reexamine and reorient how Fourth Amendment privacy protections intertwine with "the components of liberty in its manifold possibilities." 358 
$* * *$

HeinOnline -- 57 UCLA L. Rev. 70 2009-2010 